\title{
STRATIGRAPHY OF THE SOUTHERN PART OF THE SERGIPANO BELT, NE BRAZIL: TECTONIC IMPLICATIONS
}

\author{
LUIZ J. H. D'EL-REY SILVA* \& KENNETH R. MCCLAY*
}

\begin{abstract}
RESUMO ESTRATIGRAFIA DA PARTE SUL DA FAIXA SERGIPANA, NE DO BRASIL: IMPLICACÔES TECTÔNICAS A Faixa Sergipana (NE, Brasil) é uma cunha orogenética de direção geral ESE-WNW e que foi polideformada/metamorfisada em consequencia da colisão entre o Macifo Pernambuco- Alagoas, a norte, e o Cráton de São Francisco, a sul, no Ciclo Brasiliano, há cerca de 700-600 Ma, A partir de estudos anteriores em escala regional a faixa e dividida, de sul para norte, em tres domínios litotectônicos longitudinals, respectivamente assemelhados a pilhas de rochas sedimentares e vulcanicas construidas em ambiente cratdnico, miogeoclinal e eugeoclinal separados por falhas reversas, em geral de alto angulo, que indicam transporte de topo para SSW com transcorrgncia associada. Na parte norte da faixa são ainda individualizados dois outros domfnios de rochas fgneas e um domfnio de migmatitos e gnaisses.

Modelos divergentes de evolução tectônica foram produzidos para a faixa, com base em interpretações a favor e contra a continuidade lateral entre os metasedimentos. Estudos litoestratigrdficos-estruturais realizados em escala de detalhe (1987-1995) em drea de 4000km2 circundando dois domos gnáissicos de embasamento e englobando a interface entre o craton, miogeoclinal e eugeoclinal, na parte sul da faixa Sergipana, revelam: (1) uma nova litoestratigrafia das rochas depositadas nos dois domínios mais a sul, distinta daquela dos estudos anteriores; (2) evidencias sedimentológicas, estruturais, metamórficas e geofísicas inequívocas a favor da continuidade entre os três domínios, através das suas falhas de borda; (3) a parte superior da secão da cobertura cratonica compreende uma sequencia de argilito, siltito, arenito, arcósio e grauvação lítica, com granulometria crescente para o topo; esta seção passa gradativamente a metasiltito e filito depositados na bacia, onde ocorre sobreposta ao grupo basal e sotoposta a diamictitos e carbonates do grupo superior, todos depositados em tomo dos domos de embasamento que ocupam o nucleo de antiformes regionais; (4) as caracteristicas sedimentológicas e o posicionamento estratigráfico inequívoco da sequência de granulometria crescente para o topo descartam modelos tipo bacia foreland anteriormente adotados para explicar o topo da seção da cobertura cratônica adjacente a Faixa Sergipana.

Os dados permitem interpretar que o preenchimento da bacia precursora se deu em regime de sedimentacãa controlada por tectônica, no qual os domos de embasamento provavelmente atuaram como paleo-altos e as falhas regionais limitantes dos dominios (meta)vulcano-sedimentares sao provdveis falhas normals originais, que foram positivamente invertidas na fase de fechamento da bacia. A origem da parte superior da cobertura cratônica, cuja deve ser atribuída ao soerguimento e erosao de fonte a sul, e os controles tectonicos da sedimentacao, implicam consideravelmente para a evolução da Faixa Sergipana e do Cráton de São Francisco.
\end{abstract}

Palavras-chaves: estratigrafia, sedimentação e tectônica, Cinturão Sergipano, Orogenia Brasiliana, Cráton do São Francisco, Província da borborema

ABSTRACT The Sergipano Belt (NE Brazil) is a ESE-WNW trending volcano-sedimentary wedge polydeformed and metamorphosed (700-600Ma) due to the collision of the Pernambuco-Alagoas Massif, to the north, with the São Francisco Craton, to the south, during the Pan-African/Brasiliano orogeny. According to previous, regional-scale studies, the belt comprises three longitudinal lithotectonic domains with cratonic, miogeoclinal and eugeoclinal affinities, respectively from S to N, separated by regional, WNW-ESE trending, generally high-angle thrust-strike slip faults. Divergent tectonic evolution models were produced based on interpretations for and against the lateral continuity between these domains. Detailed stratigraphic-structural analysis from a 1:50,000 scale mapping carried out (1987-1995) in a 4000km2 area encompassing the interface between the three domains and surrounding two basement gneiss domes in the southern part of the belt, revealed: (1) the lithostratigraphy of the rocks deposited in the cratonic and miogeoclinal segments; (2) innequivocal evidence for the sedimentological, structural and metamorphic continuity across the domains boundary faults; (3) the upper section of the sediments deposited in the cratonic domain records the deposition of coarsening-upwards mudstones, siltstones, arkosic sandstones and lithic wackes that spreaded from the craton, to the south, across the craton-basin interface and graded into metasiltites and phyllites towards the miogeoclinal basin, where they occur in the core of a major basement-cored antiform and are overlain by a distinct diamictite formation, thus building up a siliciclastic megascquence. The sedimentological characteristics and innequivocal stratigraphic position of these arkosic sandstones and lithic wackes do not fit in previously suggested thrust-fold belt/foreland basin models; (4) very strong evidence for the miogeoclinal and eugeoclinal domains being also continuous across their boundary faults, allowing to erect a new stratigraphic template for the Sergipano Belt.

The data allow to interpret that sedimentation was tectônicaly controlled by the basement domes and normal faults likely to have been inverted during the closure of the basin. The origin of the upper section of the sediments deposited in the cratonic domain and the tectonic controls of the sedimentation have relevant implications for the evolution of both the Sergipano Belt and the São Francisco Craton.

Keywords: Stratigraphy, sedimentation and tectonics, Sergipano Belt, Neoproterozoic, Brasiliano Orogeny, São Francisco Craton, Borborema Province.

\section{INTRODUCTION - GEOLOGICAL SETTING The}

Sergipano Belt of NE Brazil is a triangle-shaped, highly deformed wedge lying between the Sao Francisco craton to the south, and the Pernambuco-Alagoas Massif to the north, the latter being part of the Borborema Province. This Province is a segment of continental crust intruded by granitoid plutons and transected by continental-scale ductile zones of high strain, such as the Patos and Pernambuco shear zones, during the Brasiliano / Pan-African Orogeny (Fig. 1, Almeida et al. 1981, Santos and Brito Neves 1984). The Sao Francisco Craton was consolidated by the end of the Paleoproterozoic and, nearby the Sergipano Belt, consists of granulites, gneiss, migmatites and granites (Fig. 2, Mascarenhas et al. 1984, Teixeira and Figueiredo 1991). The Borborema Province is a puzzle of Neoproterozoic belts and gneiss-granite blocks (Fig. 2) reworked since the Archean and/or created mostly in the 
Mesoproterozoic (Van Schmus et al. 1993, 1995), possibly representing a Neoproterozoic collage of terranes, some of them with polycyclic evolution (Jardim de Sa 1994).

The Sergipano Belt (Fig. 2) comprises six lithotectonic domains separated by generally high-angle, WNW-ESE striking thrust and strike-slip faults, and is transected by the

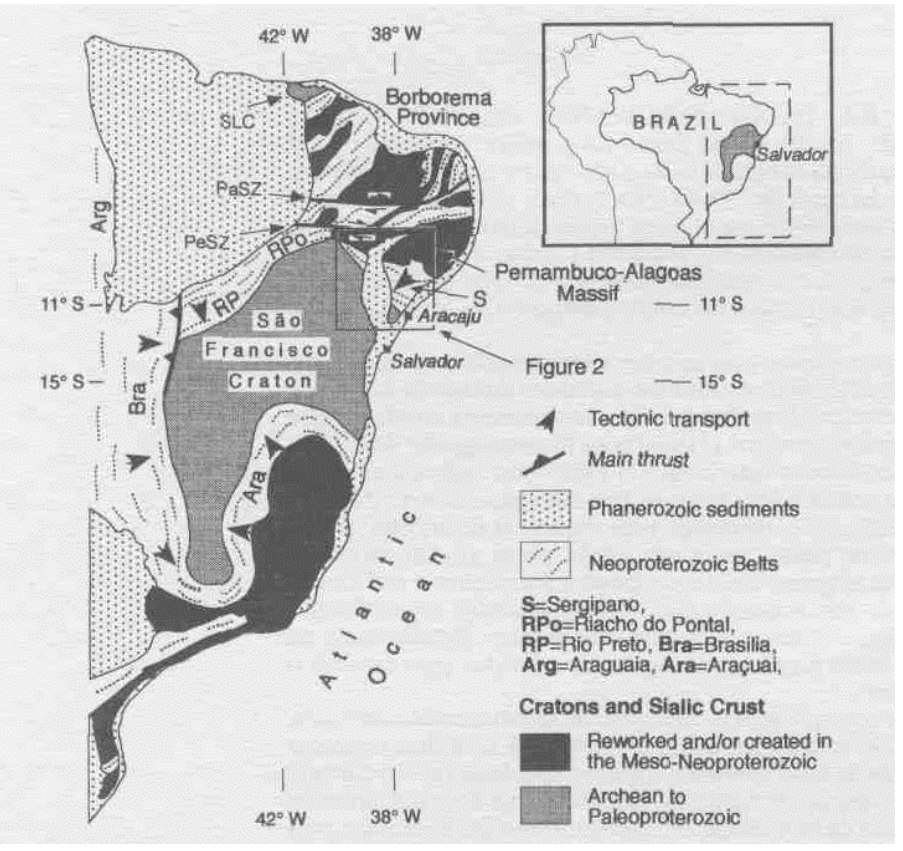

Figure 1- Major Neoproterozoic tectonic elements of eastern Brazil, highlighting the São Francisco Craton and surrounding fold belts, the Borborema Province and the Pernambuco-Alagoas Massif. SLC = São Luiz Craton, PaSZ = Patos Shear Zone, PeSZ = Pernambuco Shear Zone. Based onAlmeida et al. (1981), and Mascarenhas et al. (1984). See text.

Figura 1: Principals elementos tectonicos da metade leste do Brasil, enfatizando o Craton do Sao Francisco e suas faixas dobradas marginais, a Provmcia Borborema e o Maciço Pernambuco-Alagoas. SLC $=$ Craton Sao Luiz, PaSZ = Lineamento Patos, PeSZ = Lineamento Pernambuco. Baseado em Almeida et al. (1981) e Mascarenhas et al. (1984). Detalhes no texto.

Tucano-Jatoba and Sergipe-Alagoas Mesozoic basins. The crystalline basement crops out mostly in the Jirau do Ponciano, Itabaiana and Simão Dias amphibolite grade gneiss domes. These are mantled by and involved together with the metasediments in the deformation and regional metamorphism. Gneiss from the Simão Dias dome display a whole rock Rb-Sr $2505 \mathrm{Ma}$ age (Humphrey and Allard 1969), and orthogneisses of the Jirau do Ponciano dome display a whole rock $2500 \mathrm{Ma} \mathrm{Rb-Sr}$ isochron age (Amorim et al. 1993). Close to the belt, rocks from the São Francisco Craton and the Pernambuco-Alagoas Massif yield whole rock $\mathrm{Rb}-\mathrm{Sr}$ ages around $1800 \mathrm{Ma}$, whereas the belt has a $\mathrm{Rb}-\mathrm{Sr}$ record of a 673-600Ma old structural-metamorphic evolution (Brito Neves and Cordani 1973).

The Sao Miguel do Aleixo fault separates the Sergipano Belt in two longitudinal parts (Santos et al. 1988, Davison and Santos 1989). The northern part comprises polydeformed, greenschist to upper amphibolite facies siliciclastic and carbonate metasediments of the Macurure domain, migmatites of the Poço Redondo domain, metadacites and metarhyolites of the Maranco domain, and the basic-ultrabasic volcanics and intrusives of the Caninde domain, all being intruded by synto post-tectonic granites around $650 \mathrm{Ma}(\mathrm{Rb}-\mathrm{Sr}$ data in Brito
Neves and Cordani 1973, Chaves 1991). Currently, the lithostratigraphic units of the Macurure Group to the $\mathrm{N}$ of the Jirau do Ponciano dome and the Caninde Domain (Fig. 2) are being studied in more detail (e.g. Amorim and Torres 1994). The southern part of the belt comprises polydeformed, sub- to greenschist facies siliciclastic and carbonate metasediments of the Vaza Barris domain. The Itaporanga fault separates this domain from the cratonic Estancia domain.

The Sergipano Belt was a cornerstone in the early days of the continental-drift hypothesis (Allard 1969, Allard and Hurst 1969) and has been regarded, together with the Sao Francisco Craton, as a key for the study of crustal evolution in the Neoproterozoic (e.g. Davison and Santos 1989, Murphy and Nance 1991). Compared with other Pan-African/Brasiliano belts (e.g. Trompette 1994), the Sergipano Belt has almost unique gneiss domes around which well preserved metasedimentary cover and basement-cover relationships are observable, particularly around the two domes of its southern part.

Based on fundamental lithological descriptions by Humphrey and Allard (1968, 1969), Jordan (1971) and Silva Filho (1976), the first stratigraphic framework was established by Silva Filho et al. (1978 a,b), and Silva Filho and Brito Neves (1979), who divided the sedimentary-volcanic rock record of the Sergipano Belt in the Estancia, Miaba/Vaza Barris and Macurure groups (Fig. 2) and interpreted it in terms of the laterally continuous, cratonic, miogeoclinal and eugeoclinal domains of a single basin deepening northwards away from the São Francisco Craton. The cratonic domain comprises the Estancia Group, which rests unconformably on the craton and is sub-divided into three formations (lower argillites, sandstones and conglomerates; intermediate carbonates; and upper mudstones, siltstones and sandstones), and the Palmares Formation (Fig. 2; massive sandstones, local conglomerates and lithic wackes), resting unconformably on both the Estancia Group and the craton. The miogeoclinal domain comprises the basal Miaba Group, unconformably deposited around the Itabaiana dome and consisting of basal quartzites (minor conglomerates), intermediate pebbly phyllites, meta-argillites and greywackes, and upper metacarbonates. The Vaza Barris Group, spreading on the rest of the domain, and consisting of phyllites, metagreywackes, metavolcanics, metadiamictites and metacarbonates. The eugeoclinal domain comprises the Macururé Group (basal quartzites and upper schists and metavolcanics, all intruded by granites) and the unconformably overlying Jua Formation (undeformed coarse-grained siliciclastics). The latter is deposited in a small graben nearby the eastern border of the Tucano basin (Fig. 2).

Those authors adopted a model (also in Silva Filho 1982) whereby the syn-tectonic erosion of a collisional thrust-andfold belt would supply terrigenous sediments for the unconformable deposition of the Palmares and Jua formations, respectively as foreland and intramontane basin deposits supplied from the north. Many authors maintained these ideas and postulated tectonic models for a frontal collision of the Pernambuco-Alagoas Massif and the Sao Francisco Craton (e.g. Brito Neves et al. 1977, Jardim de Sa et al. 1981, 1986, Campos Neto and Brito Neves 1987). However, challenging the concept of a single basin, Santos et al. (1988) and Davison and Santos (1989) defined the Maranco, Poço Redondo and Caninde domains after a 1:100,000 scale geological mapping of the central part of the belt, and interpreted the six lithotectonic domains of the Sergipano Belt as terranes accreted during oblique collision.

Even after Saes (1984) has described in detail a gradual transition throughout the cratonic sediments, arguing for caution on the origin of the Palmares Formation, then incorporated at the top of his Estancia Group, the whole stratigraphy of the belt and the thrust belt-foreland basin model remained 


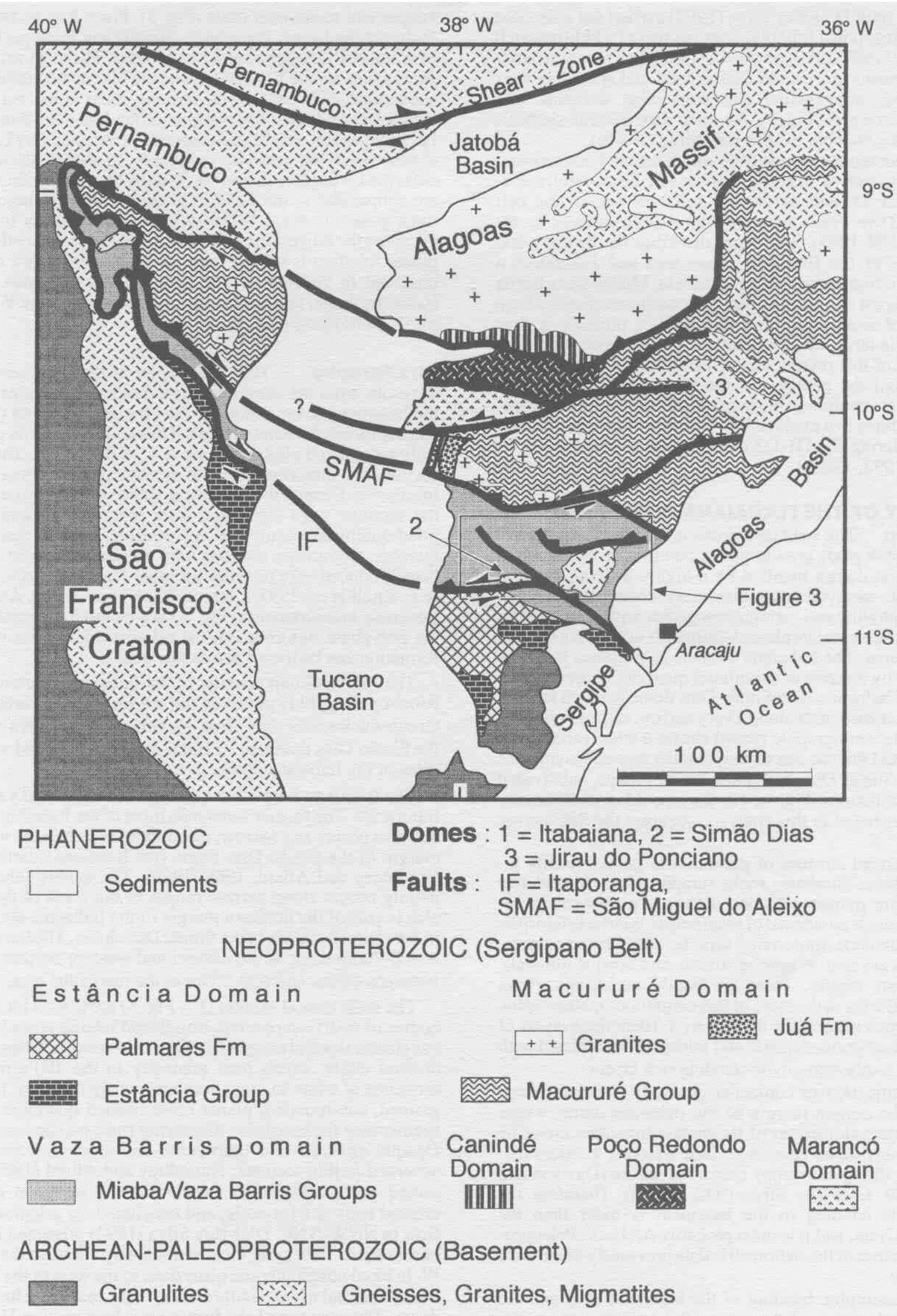

Figure 2 - Simplified geological map of the Sergipano Belt. Based on D'el-Rey Silva (1992), Davison and Santos (1989), Jardim de Sá et al (1986), Gava et al. (1983), Brito Neves et al. (1977). See text.

Figura 2 - Mapa geológico simplificado da Faixa Sergipana. Baseado em D'el-Rey Silva (1992), Davison and Santos (1989), Jardim de Sá et al. (1986), Gava et al. (1983), Brito Neves et al. (1977). Detalhes no texto. 
undisputed until D'el-Rey Silva (1992) carried out a detailed geological mapping (1:50,000 scale) as part of a $\mathrm{PhD}$ research programme (1989-1992) on the 4,000km2 key area surrounding the Itabaiana and Simão Dias domes, and spreading over the cratonic, miogeocline and eugeocline domains (the Itabaiana dome area, Fig. 2). An up to date tectonic sinthesis of the belt is available in D'el-Rey Silva (1995b).

This paper reports the analysis which resulted in a substantial reassessment of the stratigraphy and lithostratigraphicstructural correlations across the southern part of the belt (D'el-Rey Silva 1992), coupled with data from more recent research (1993-1995). The paper describes the geology and stratigraphy of the Itabaiana dome area and introduces a stratigraphic framework for the Estância, Miaba/Vaza B arris and Macururure domains, as part of a continuous basin whose evolution of architecture and sedimentary infilling is then interpreted in terms of tectônically controlled sedimentation. The results of this research have also allowed to describe in enough detail the geology of the basement domes and to interpret their evolution in terms of syn-depositional extensional structures that evolved into basement-cored overturned antiforms during the D1-D3 deformation of the area (D'elRey Silva 1992, 1995a).

\section{GEOLOGY OF THE ITABAIANA DOME AREA In-} troduction The Itabaiana dome area (Fig. 3) comprises an amphibolite grade granite-gneiss complex cropping out in two basement domes mantled by a highly deformed greenschist grade metavolcano-sedimentary cover of quartzite, diamictite, phyllite and carbonate, together with almost undeformed and nonmetamorphosed sediments occupying the SW part of the area. The Itabaiana dome is an elliptical structure surrounded by a series of prominent quartzite ranges around the town of Itabaiana. The Simão Dias dome is much smaller and continues eastwards along a very narrow strip of mylonitic gneisses. The stratigraphic record shows a wide variation of lithofacies and thicknesses throughout the area and comprises the Miaba, Simão Dias and Vaza Barris groups, subdivided into eight formations (Fig. 4). The Sergipe-Alagoas Mesozoic basin, not included in this analysis, occupies the SSE corner of the area.

The basement consists of granodiorite gneiss, locally intruded by basic-ultrabasic rocks (amphibolites, hornblende gabbro, minor pyroxenites) and deformed porphyritic granites. The gneiss is composed of plagioclase, quartz, k-feldspar, biotite, hornblende, muscovite, sericite, chlorite and epidote. Accessories are apatite, sphene, zircon, and opaque minerals. Garnet occurs locally. These are highly anysotropic rocks basically differing in the more or less continuous metamorphic banding, which is normally defined by $1-10 \mathrm{~cm}$ thick layers of fine to medium grained quartz and feldspars intercalated with $\leq \mathrm{lcm}$ thick biotite-muscovite- epidote rich layers.

The basement/cover contact is generally sheared, except locally in the eastern margin of the Itabaiana dome, where basal (meta)conglomerates of the metasedimentary cover lie unconformably on an erosion surface affecting gneisses displaying the strong anisotropy described before (Davison and Santos 1989, D'el-Rey Silva 1992, 1995a). Therefore the metamorphic banding in the basement is older than the Brasiliano Cycle, and it is most probably Archean- Paleoproterozoic because of the radiometric data previously mentioned in this paper.

The metamorphic banding of the basement $(\mathrm{Sn})$ and the sedimentary layering of the cover (So) both record similar polyphase deformational evolution attributable to the Brasiliano Orogeny. The main mappable structures are subvertical, WNW-ESE trending thrust, strike-slip, normal faults and major F2 phase folds, whereas a major stratigraphic inversion on the western border is ascribed to Fl-related nappes and recumbent folds (Fig. 3). From $\mathrm{S}$ to N, the main faults are the Jacare, Itaporanga, Simão Dias, Escarpa, Pelada, Mocambo, Ribeiropolis and Dores faults. The main strike-slip shear zones are the Vaza Barris and the Mocambo faults. Other subvertical, NW-SE to E-W striking shear zones cut across the eastern and southern margins of the Itabaiana dome. The Itaporanga fault roughly corresponds to the boundary between almost flat-lying cratonic sediments, to the south, and the deformed wedge to the north. Within this wedge Sn and So are subparallel to the S1//S2 foliations. Overall these structures generally trend WNW-ESE and dip steeply to NNE, except in the hinge zones of the larger F2 folds where the axial planar foliation is steeper than the folded structures, such as observed in the interior and along the western side of the Itabaiana dome, and the Paripiranga anticline to the $\mathrm{W}$ of the Simão Dias dome (Fig. 3).

Stratigraphy The stratigraphy of the study area (Fig. 4) results from the combination of data on 12 sections across the basement-cover contact around the gneiss domes (Fig. 5) and comprises the Miaba, Simão Dias and Vaza Barris groups, fully recognized along sections $\mathrm{AA}^{\prime}, \mathrm{BB}^{\prime}$ and $\mathrm{JJ}^{\prime}$. The other sections are important to show the lateral equivalence of the lithofacies. Despite the area is not $100 \%$ covered by outcrops, the sections were composed after the study of numerous, good-quality exposures along streams, rivers, roads and quarries. Composite sections with these characteristics have been produced very recently for other Neoproterozoic basins (e.g. Knoll et al. 1995, Christie-Blick et al 1995). Although thickness measurements (Fig. 5) are generally hampered by the polyphase deformation, the relative thicknesses of each formation can be traced across the area.

The Miaba Group consists of the Itabaiana quartzites, the Ribeiropolis pebbly phyllites and the Jacoca metacarbonates. Group thicknesses vary from $\approx 200 \mathrm{~m}$ on the western side of the Simão Dias dome, to $\approx 1100 \mathrm{~m}$ on the eastern and western sides of the Itabaiana dome.

The Itabaiana Formation consists of a sandy and a muddy lithofacies. The former surrounds most of the Itabaiana dome and also occurs as a narrow, discontinuous belt in the western margin of the Simão Dias dome (the Itabaiana quartzites of Humphrey and Allard, 1968, 1969). The muddy lithofacies mainly occurs along narrow ranges to the north of the area, also in part of the northern margin of the Itabaiana dome and in the western margin of the Simão Dias dome. The Formation is $400-700 \mathrm{~m}$ thick in the eastern and western borders of the Itabaiana dome, and $\leq 30-200 \mathrm{~m}$ in the rest of the area.

The most typical section (JJ', Fig. 5) starts with local, thin bodies of matrix-supported, trough and tabular cross-bedded conglomerates and conglomeratic sandstones, with basementderived clasts, which pass gradually to the 100 's m-thick sequence of white to grey, homogeneously medium- to finegrained, sub-rounded, planar cross-bedded quartzites (feldspathic near the base) also displaying fluid-escape structures. Opaque minerals and tourmaline are common accessories observed in thin sections. Humphrey and Allard (1969) presented paleocurrent data from relatively common tabular crossed beds at $\leq \mathrm{lm}$-scale, and concluded for a sedimentary flow to NNW-NNE. D'el-Rey Silva (1992) presented further observations indicating local sedimentary flows to the $\mathrm{E}$ and $\mathrm{W}$, in basal conglomeratic quartzites, to the west of the Simão Dias dome and in the middle section to the east of the Itabaiana dome. The very top of the formation, along section JJ', consists of grey to brown-red, fine-grained metasandstones, metasiltites and meta-argillites, or may also consist of thin lenses of conglomerattic quartzites with $\leq \mathrm{lcm}$-size, generally rounded basement-derived clasts. The muddy lithofacies consists of micaceous quartzites and/or 10-100cm-thick layers of 

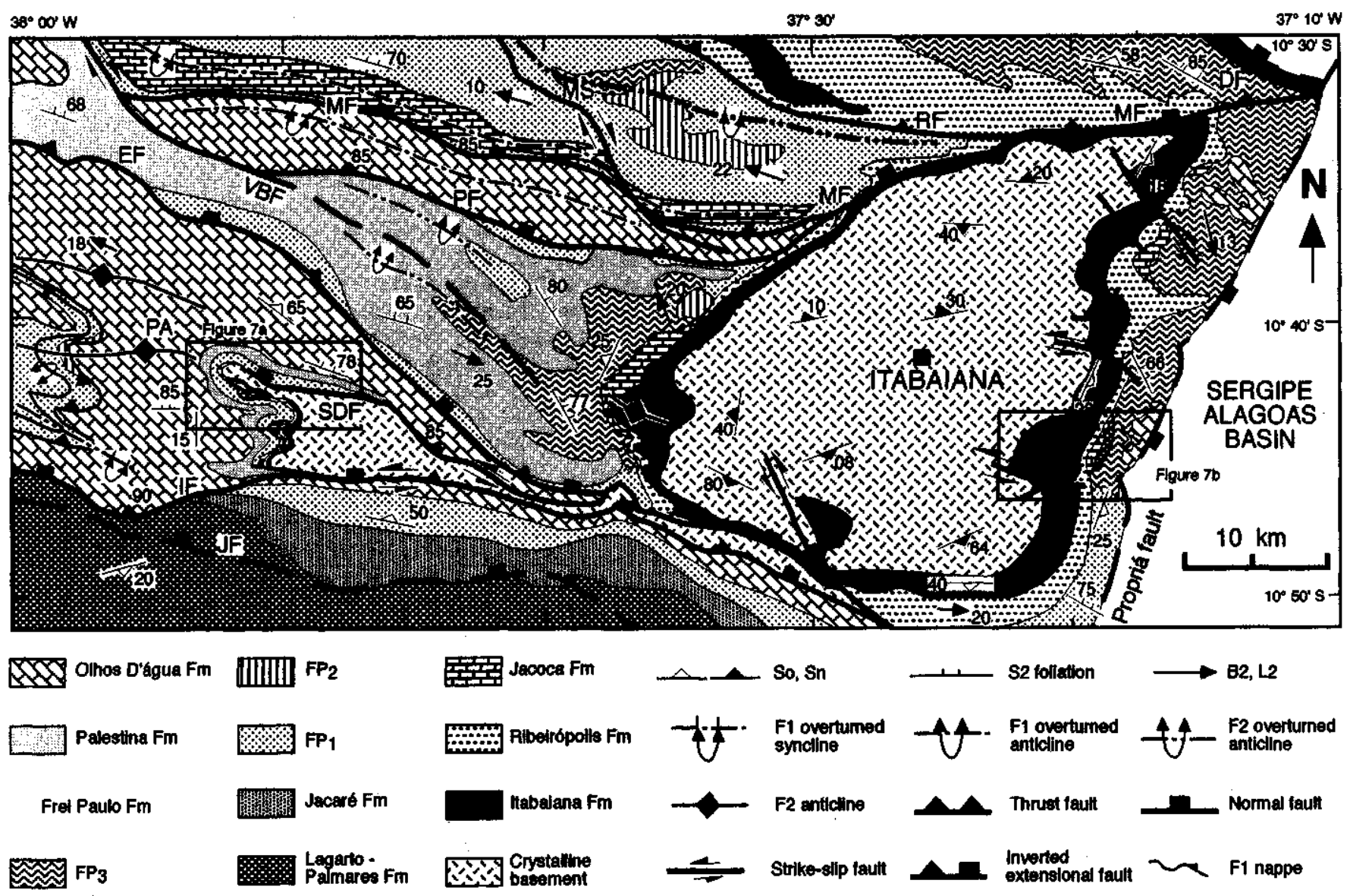

$P A=$ Pariptranga anticilne, JF = Jacare fautt, IF = Haporanga fauth, SDF = Sinao Dies fauti,

MF = Mocambo fault, MS = Mocambo shear, RF = Ribeirópolis teult, DF = Dores fault

Figure 3 - Simplified geological map of the Itabaiana dome area. FromD'el-Rey Silva (1992). See text. Figura 3 - Mapa geoló gico sumário da área do domo de Itabaiana, baseado em D'el-Rey Silva (1992). Detalhes no texto.

arkosic sandstones or wackes, intercalated with red brown phyllites.

The Ribeiropolis Formation (D'el-Rey Silva 1992) consists of light brown silty phyllites with intercalations of fine metagrey wackes and pebbly phyllites/metarkoses, but may be represented only by intermediate metavolcanics or metaconglomerates (sections BB' and EE', Fig. 5). It is $\approx 100 \mathrm{~m}$ thick in the western margin of the Simão Dias dome and may be absent or attain $\approx 300 \mathrm{~m}$ on both the eastern and western margins of the Itabaiana dome. Thickness $\geq 500 \mathrm{~m}$ is likely to occur on the southern and northern margins of this dome. The contact is generally gradational with the Itabaiana Formation, but is sheared along a top to ESE low-angle ramp, in one locallity of the western margin of the Itabaiana dome.

Due to the variety of lithofacies, this formation lacks a type-section, but generally the pebbly phyllites and metaconglomerates occupy basal positions and the phyllitic facies occurs towards the top of the unit. The best section (JJ', Fig. 5) starts with white to grey or light brown, silty meta-argillites with parallel stratification, containing intercalations of up to $10 \mathrm{~m}$-thick metagrey wackes and graded bedded conglomeratic metasandstones and pebbly phyllites, with clasts from basement rocks and quartzite. This sequence passes to finely laminated grey meta-argillites and light brown metasiltites, which are overlain by light brown, calcareous phyllites with intercalations of carbonaceous phyllites, suggesting a gradual transition upwards into the Jacoca Formation.

To the north of the Itabaiana dome (along section GG', Fig. 5) the Ribeirópolis Formation starts with red brown to purple silty phyllites seen in gradual passage with the Itabaiana Formation, and proceeds northward with intercalated pebbly phyllites, light brown-purple phyllites and possibly porphyroclastic volcanic rocks with similar colours. Weathered metarhyolites and metadacites have been described as part of this sequence, immediately to the north of the Itabaiana dome area (Santos et al 1988).

The Jacoca Formation conformably overlies the Ribeirópolis Formation and rests unconformably on Itabaiana quartzites, to the west of the Itabaiana dome (section EE', Fig. 5). It comprises lithofacies of metacarbonates and metarhythmites.

The typical section (Fig. 6) starts with a 3 m thick layer of laminated white-light grey, $1-3 \mathrm{~cm}$ thick beds of metadolomite containing $\approx \mathrm{lcm}$ thick beds of pyrite and chalcopyrite. These are overlain by $\mathrm{a} \approx 15 \mathrm{~m}$ thick layer of metarhythmites, which consist of intercalated, laterally continuous, up to $10 \mathrm{~cm}$-thick layers of thinly laminated metadolomite, light brown metachert and dark grey to black, calcareous phyllite, overlain by a $\approx 10 \mathrm{~m}$-thick column of $1 \mathrm{~m}$-thick layers of massive 


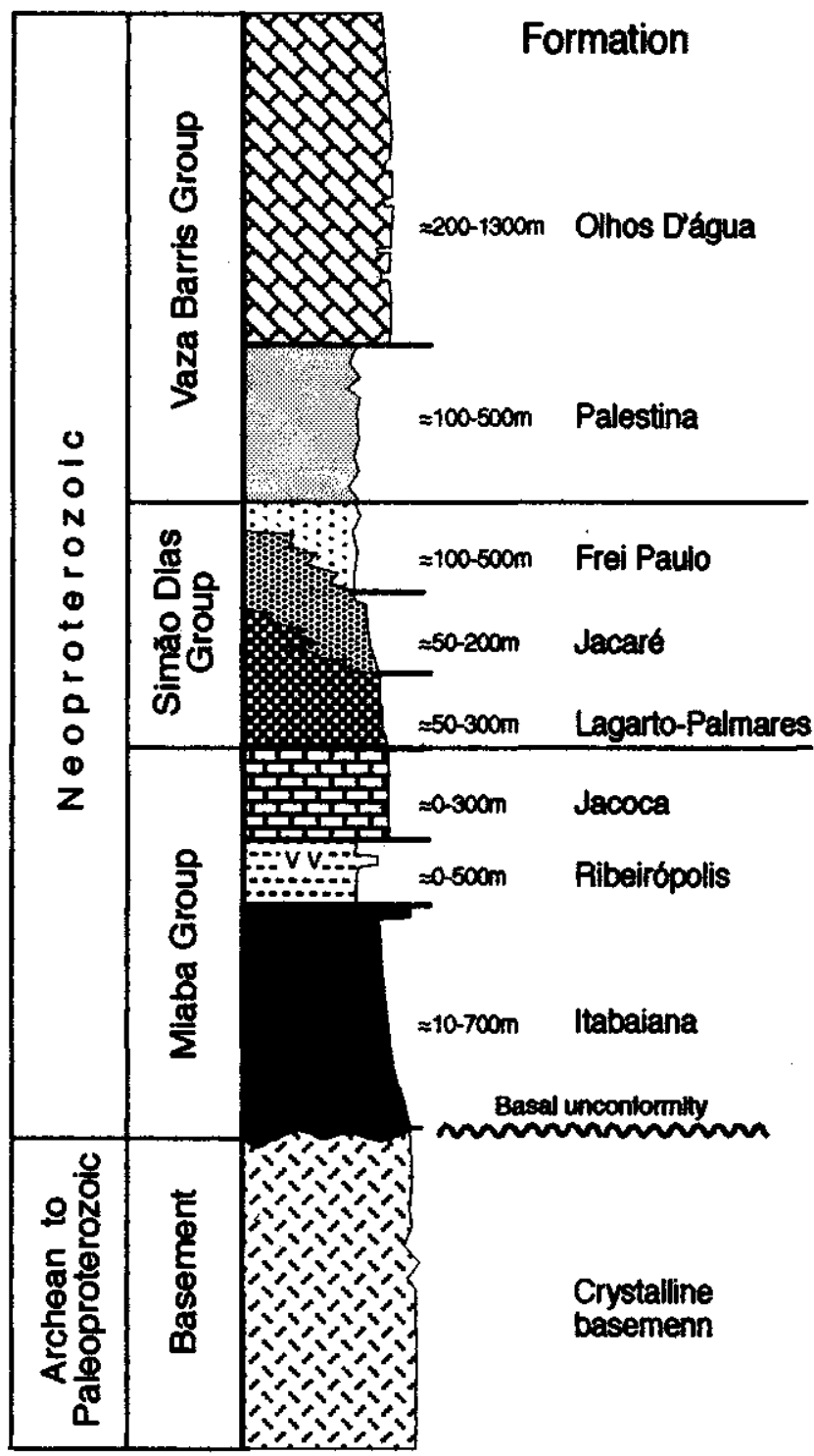

Figure 4 - Summary stratigraphy of the Itabaiana dome area. FromD'el-Rey Silva (1992). See text for details.

Figura 4 - Sumdrio da estratigrafia da drea do domo de Itabaiana, baseado em D'el-Rey Silva (1992). Detalhes no texto.

metadolomite. Thin section of the thinly laminated metadolomite displays a typical marble texture of equigranular recrystallised calcite grains, interbedded with $\approx$ lmm-thick layers of sericite, chlorite, biotite, very fine-grained quartz and feldspar defining a layer-parallel foliation. This unit is overlain by a $\approx 40 \mathrm{~m}$ thick sequence of intercalated, $\approx 1-10 \mathrm{~cm}$ thick layers of grey metalimestone, calcarenite and dark grey-black, locally carbonaceous phyllite. These units display parallel laminations, wave-truncated current ripples and pass upwards into a $\approx 200$ m thick sequence of $\approx 1 \mathrm{~m}$ thick layers of light grey metadolomites. Primary structures such as parallel lamination, fluid-escape structures, small-scale wave-reworking structures and tabular cross stratifications are observed in the western margin of the Itabaiana dome. In this area, Guimaraes et al. (1991) also described abundant oolites and intraclasts, respectively in the lower and upper section of the Jacoca Formation. In the western side of the Simão Dias dome the metarhythmites consist of $\leq 100 \mathrm{~m}$ thick layers of brown-grey phyllites with $\leq 10 \mathrm{~m}$ thick layers of white to grey metadolomite which was disrupted and occurs in lenses, probably due to the deformation. To the north of the Mocambo fault (Fig. 3) the metarhythmites are defined by generally continuous, $\leq \mathrm{lm}$ thick layers of dark grey-black, fine-grained metalimestone, intercalated with $\approx 10 \mathrm{~cm}$ thick layers of light brown to dark or variegated metapelites, metasiltites and minor, fine-grained metasandstones.

The Simão Dias Group is a $\approx 400-700 \mathrm{~m}$ thick coarseningupwards siliciclastic sequence deposited on the Craton and in the basin. It conformably overlies the Miaba Group in the studied area, and comprises the interfingered Lagarto-Palmares, Jacare and Frei Paulo formations. The group is a new stratigraphic unit identified in the southern part of the Sergipano Belt and the name refers to the tectonicaly significant outcrops found principally to the west of the Simão Dias dome, in the core of the Paripiranga anticline (section BB' and Fig. 7a). This group was originally termed Lagarto Group by D'el-Rey Silva (1992) who also described the complete sections JJ' (Fig. 5 and Fig. 7b) and LL' (Fig. 8). The new name is to avoid confusion with the well known Lagarto Formation.

The Lagarto-Palmares Formation (D'el-Rey Silva, 1992) in general conformably overlies the Jacoca Formation, but the outcrops along section BB' rest above outcrops of Ribeiropolis metavolcanics. This may suggest an unconformable relationship due to the lack of the Jacoca Formation, though not proven because the direct contact is not observed. The formation also lies in fault contact with the crystalline basement, far to the south, in the São Francisco Craton (Silva Filho 1982, Saes 1984). The formation comprises a $\approx 200 \mathrm{~m}$ thick basal unit of mudstones and siltstones with lenses of fine-grained, planar cross-bedded sandstones which occur in the southern limit of the Itabaiana dome area (Fig. 8a). This unit spreads from the craton onto the basin's border and gradually passes up-section, towards the north, into an intermediate unit consisting of $\approx 200 \mathrm{~m}$ of fine-grained sandstones with repeated cycles of parallel lamination capped by small-scale, symmetric wave ripples. Sharp truncation surfaces are observed at the base of each cycle. This unit is $\approx 200 \mathrm{~m}$-thick and consists of $10 \mathrm{~cm}-$ thick layers of fine- to medium-grained, brown to grey, micaceous, parallel laminated (meta)sandstones, with $\approx 5 \mathrm{~cm}$ scale abundant symmetric wave ripples.

Upwards, these rocks pass gradually into the upper unit (Fig. 9), $\mathrm{a} \approx 120 \mathrm{~m}$ thick sequence consisting of metre-scale layers of massive or parallel laminated, greenish grey, calcitecemented, micaceous fine- to medium-grained sandstones and lithic wackes, with intercalations of laterally continuous, $\approx$ lcm-thick layers of red-brown mudstones. D'el-Rey Silva (1992) described wavy-surfaces of truncation of the sandstone layers and sigmoidal-shaped surfaces of truncation of the muddy layers, above which micaceous sandstone layers were deposited, indicating an interplay between periods of quiescence and periods of sedimentation with higher energy, and also described $\leq 1 \mathrm{~cm}$-thick continuous muddy layers commonly disrupted into $\leq 10 \mathrm{~cm}$-wide disk-like mudstone fragments, forming local intraformational breccias or laterally continuous thin layers of platy, reddish brown fragments. Petrographically, the upper unit consists of submature massive sandstones composed of subangular to subrounded, generally $0.15-0.45 \mathrm{~mm}$ size grains of quartz, K-feldspar, plagioclase, opaque minerals, zircon, granite, aggregates of microcrystalline quartz, calcite, epidote, and flakes of muscovite and chlorite. The erosion of these rocks commonly result into $\approx 1 \mathrm{~m}$-size rounded boulders that dominate the topography, and this erosion pattern is controlled by the intersection of bedding and orthogonal fractures (Fig. 8b).

The lower and intermediate units belong to the Lagarto Formation, whereas the upper unit stands for the Palmares 


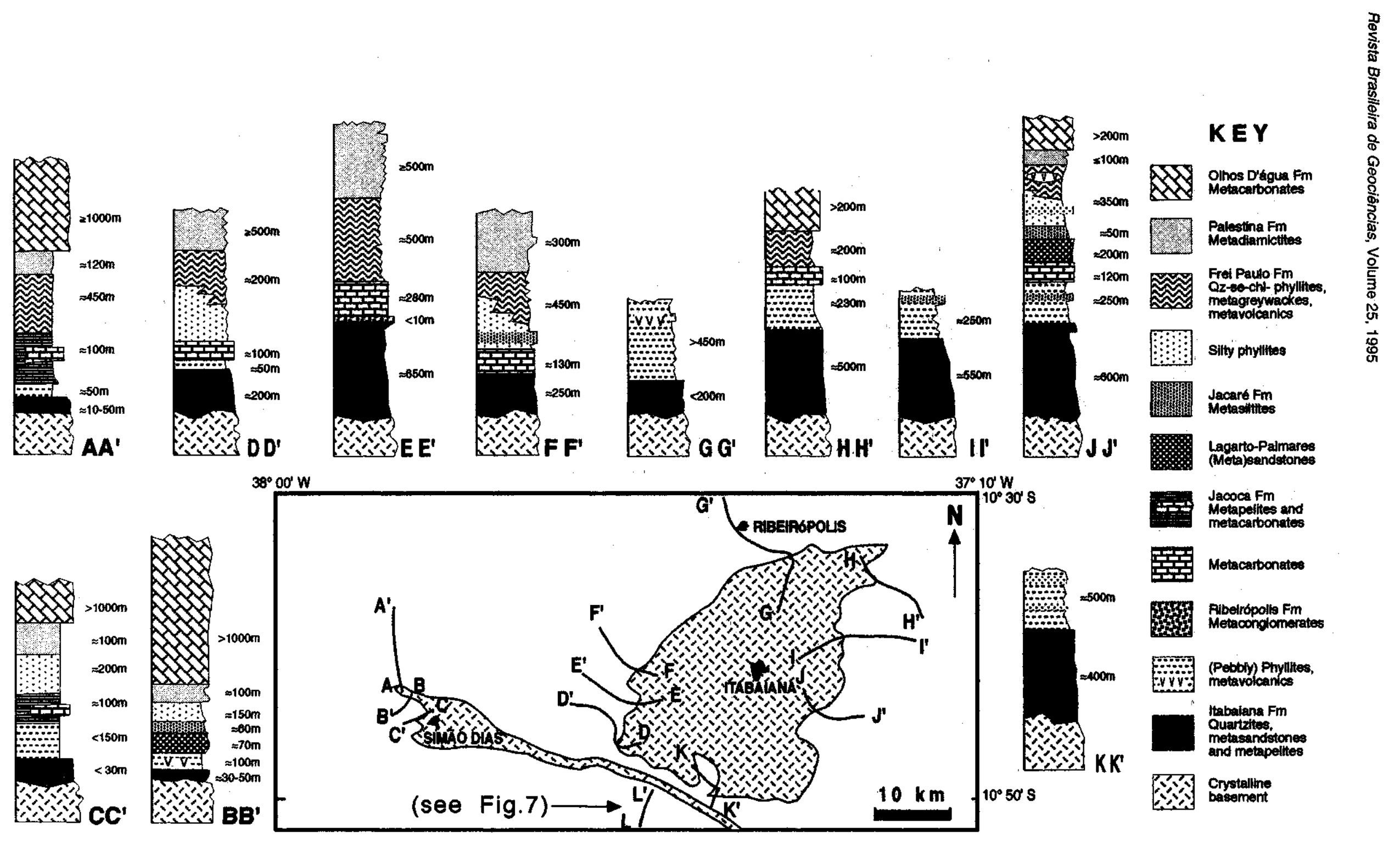




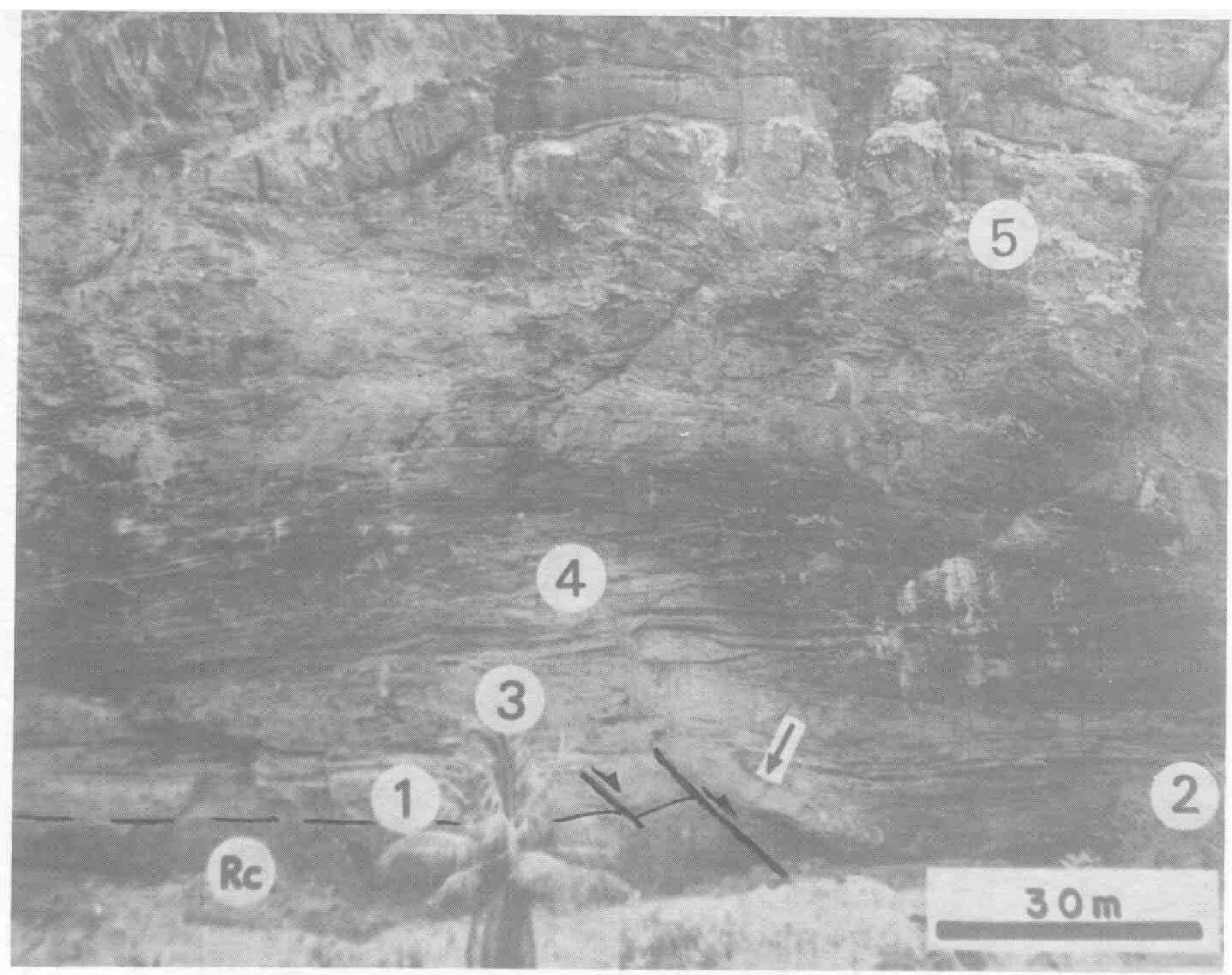

Figure 6 - The Jacoca Formation in the Capitão farm outcrop (western margin of the Itabaiana dome) resting in sharp contact above the Ribeiropolis conglomerates (Re) which are truncated by a normal fault dipping to the north: $1=C u$ and $S$-bearing basal dolomite; 2 - thinly interbedded metadolomite, metachert, calcareous phyllite; 3 = metadolomite (arrowed in the core of the fold in the hangingwall of the normal fault); 4 - thinly intercalated metalimestones and dark grey-black phyllites; 5 - thicker, more massive, metadolomites and metalimestones.

Figura 6 - A Formacao Jacoca no afloramento da Fazenda Capitão, margem oeste do domo de Itabaiana. Ocorre sotoposta em contato brusco a conglomerados da Formação Ribierópolis (Re), os quais sao truncados por falha normal que mergulha para norte: 1 = metadolomito basal portador de Cu e S; $2=$ metadolomito com intercalafoes delgadas de metachert e calci-filitos; 3 = metadolomitos e fllitos pretos a cinza escuro (no nucleo da dobra apontada pela seta, na capa da falha normal); 4 = metacarbonatos fmamente acamadados, com intercalaçães delgadas de filitos pretos a cinza escuros; $5=$ metadolomitos e metacarbonatos mais maci9os, em camadas de espessura metrica.

Formation of Silva Filho et al. (1978 a,b) and Silva Filho (1982). The overall estimated thickness of the Lagarto-Palmares Formation in the Itabaiana dome area $(\approx 720 \mathrm{~m}$; Fig. 9) fits with the thickness proved below the Tucano Basin by oil industry wells (Silva Filho et al., 1978b). However, the maximum thickness of the upper unit is actually unknown, as it is truncated by the topography. A section of $\approx 2500 \mathrm{~m}$ is found in a partially fault-bounded depocentre where the formation is in contact with the crystalline basement, far in the cratonic area (Saes, 1984). This author described in detail a gradual contact relationship between the Lagarto and Palmares Formations, too, in an area $\approx 100 \mathrm{~km}$ to the south of the Itabaiana dome. In addition, Saes (1984) showed detailed paleocurrent data indicating a sedimentary flow to NNE, during the deposition of the Lagarto and Palmares Formations.

Altogether, the large inventory of data mentioned up to here makes hard to believe that the origin of the Palmares Formation lies on the erosion of the Sergipano Belt. Just in contrary, as D'el-Rey Silva stated (1992), the Palmares Formation must reflect the erosion of high grade granite-gneiss terranes and low grade supracrustals (greenstone belts) that are found to the south, in the São Francisco Craton, relatively close to the basin's border, and this explains the composition of the Lagarto-Palmares arkoses and lithic greywackes. In fact these formations are truly interfingered, as demonstrated by further field observation (1993-1995) by the main author, C.A. Rosiere (UFMG) and B.B. Brito Neves (USP): 1 - lm-thick, laterally continuous layers of typical Palmares sandstones 

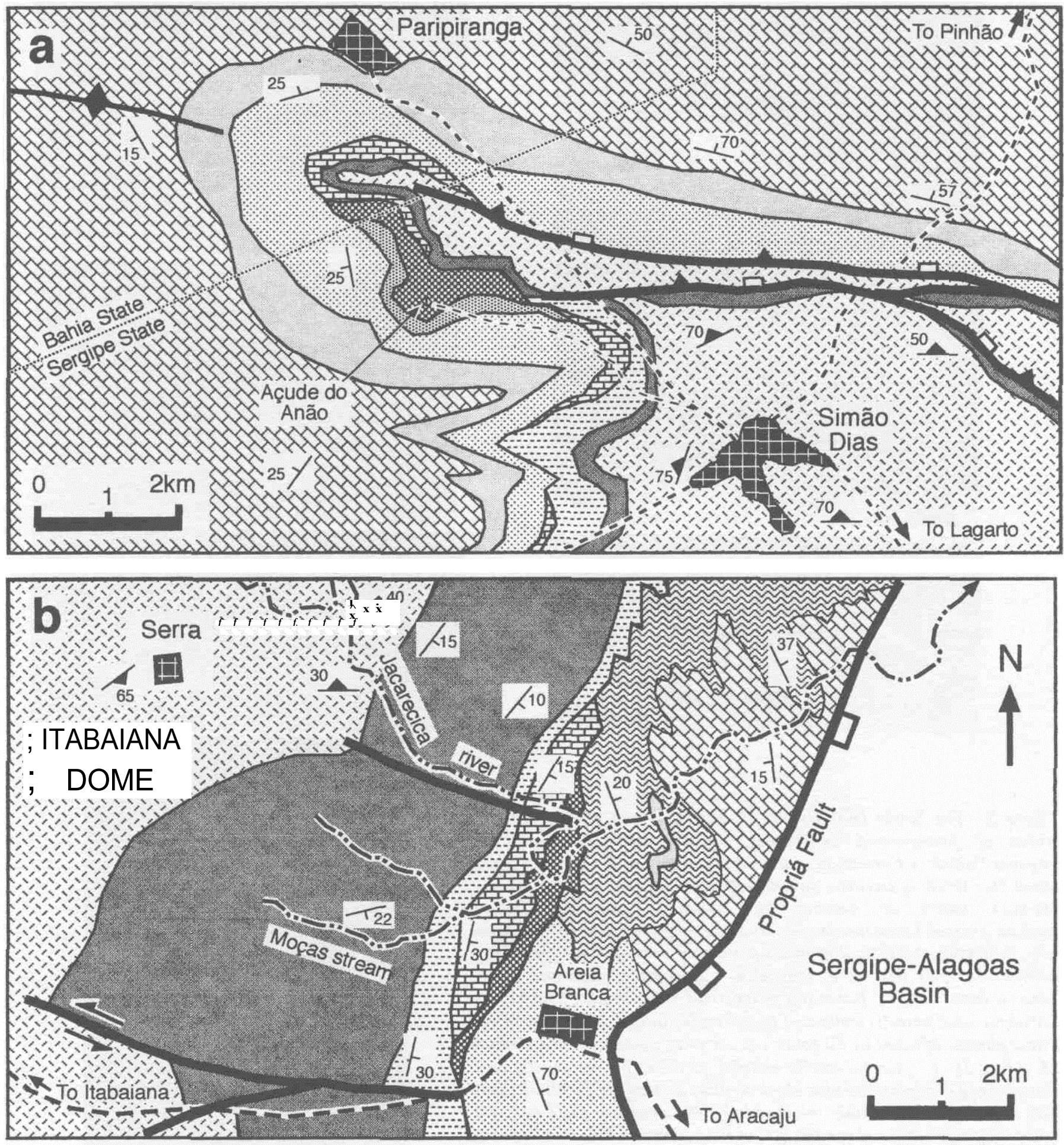

Figure 7 - Simplified geological map of the areas indicated in Figure 3. The Simão Dias Group occurs in the core of the basement-cored antiform to the west of the Simão Dias dome, around the locallity of Açude do Ando (a), and to the east of the Itabaiana dome, between the Moças stream and the Jacarecica river (b). Legend as in Figure 3, adding some towns, villages and roads. From the 1:50,000 scale geological map elaborated by D'el-Rey Silva (1992).

Figura 7 - Mapa geológico das areas indicadas na Figura 3, mostrando a ocorrencia do Grupo Simão Dias no centra do antiforme cujo nucleo e o embasamento do domo de Simão Dias, na localidade do Açude do Anão (a) e a leste do domo de Itabaiana, entre o riacho das Moças e o rio Jacarecica (b). Legendas como na Figura 3, acrescentando as cidades, vilarejos e estradas de acesso. Elaborado a partir do mapa geologico na escala 1:50.000 produzido por D'el-Rey Silva (1992). 

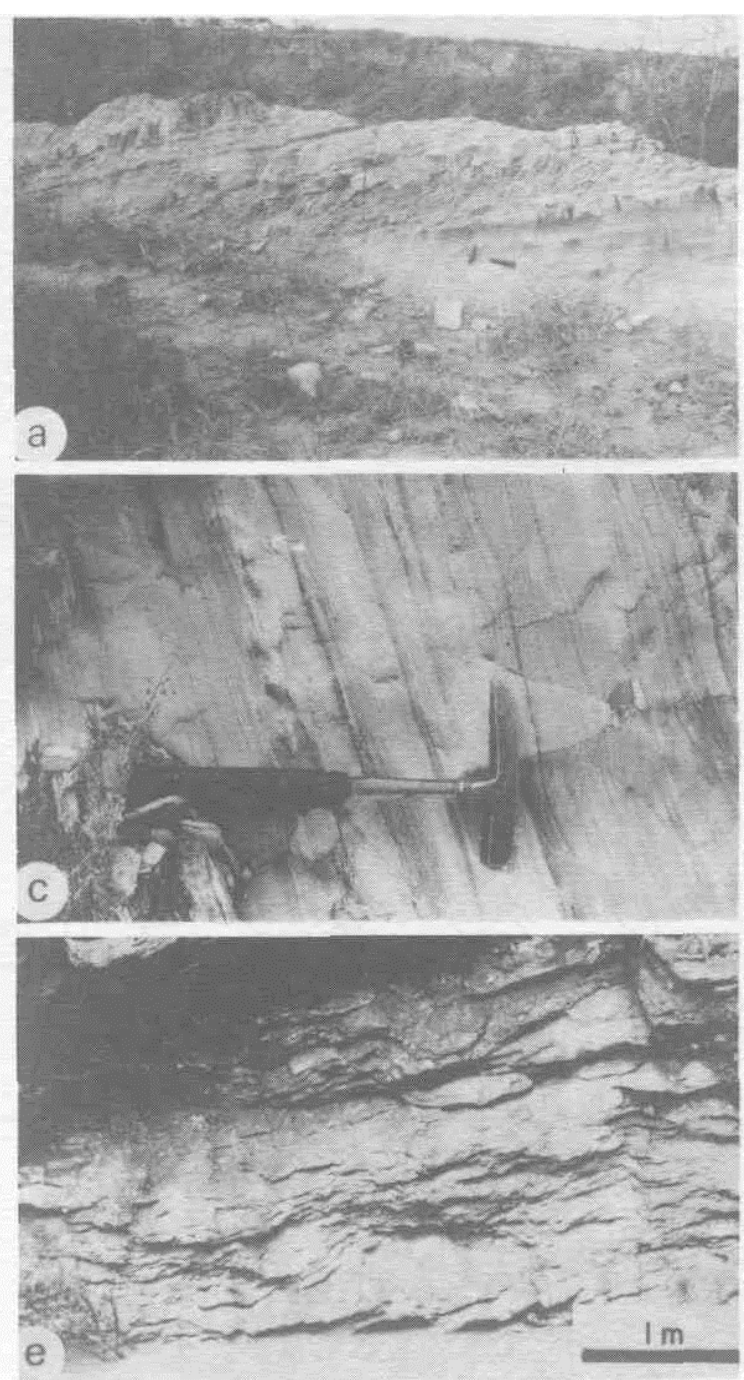

Figure 8 - The Simtio Dias Group: a -Siltstones and mudstones with lenses of fine-grained sandstones, in the basal unit of the Lagarto-Palmares Formation at the southern limit of the mapped area, about $5 \mathrm{~km} W N W$ of Lagarto, paved road to the town of Simão Dias; $b$ Jm-thick layers of massive and parallel laminated, fine-to medium-grained (meta) sandstones and (meta)greywackes of the upper unit, displaying the typical rounded pattern of erosion. The $30 \mathrm{~cm}-l o n g$ hammer (arrow) lies on a Icm-thick, intercalated mudstone layer. Limeira farm, Lagarto-Itabaiana paved road (section LL', Fig. 5); cVariegated and parallel laminated Jacare metasiltite; $d$-Variegated Frei Paulo phyllite affected by $F 2$ folds, $c$-d are from outcrops along section LL' (Fig. 5); e - quartz-sericite-chlorite phyllite; $f$ - metarhythmites consisting of thinly interbedded black phyllite, metasiltite, calcilutite and silty phyllite; and $g$ - thinly interbedded metalimestones (LST arrows) and metagreywackes, where the 30-cm long arrowed hammer lies, e-g are from outcrops in the area between the Escarpa and Pelada faults, close to the Itabaiana dome.

Figura 8 - O Grupo Simão Dias: a - Siltitos e argilitos com lentes de arenitos finos da unidade basal da Formação Lagarto-Palmares, no limite sul da área mapeada, cerca de 5km a WNW de Lagarto, ao longo da estrada para Simão Dias; b - Camadas de espessura métrica de (meta)arenitos com laminação paralela e de granulometria fina a média, e de (meta) grauvacas da unidade superior, mostrando o padrão tipico de erosão em blocos arredondados; c - Metasiltitos Jacaré finalmente acamadados; d - Filitos Frei Paulo afetados por dobras F2; c-d são de afloramentos ao longo da seção LL' (Fig. 5), estrada Lagarto-Itabaiana; e Quartzo-sericita-clorita filitos; f - Metaritmitos formados por fmas intercalações de fllitos cinza escuros a pretos, metasiltitos, filitos calcíferos e filitos sflticos; gintercalates de metacarbonatos (setas) em metagrauvacas. e-g são de afloramentos na área entre as falhas Escarpa e Pelada, proximos ao domo de Itabaiana. 


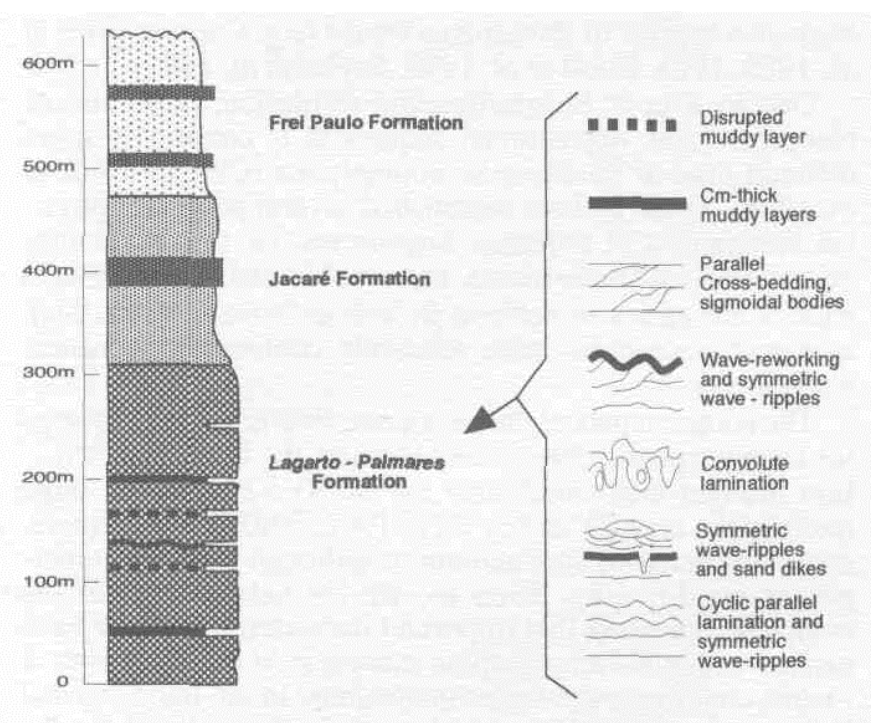

Figure 9 - Stmtigmphic section $L L^{\prime}$ displaying the typical features of the intermediate and upper units of the Simão Dias Group along the Lagarto-Itabaiana paved road, in the site of the Limeira farm and Vaza Barris river (location in Fig. 5). The primary structures to the right occur in the vertical sequence indicated within the Lagarto-Palmares Formation. Adapted from D'el-Rey Silva (1992). See text for details. Figura 9 - Seção estratigráfica LL' mostrando as feifoes sedimentares tipicas das unidades intermediaria e superior do Grupo Simão Dias, ao longo da estrada Lagarto-Itabaiana (Fazenda Limeira) e rio Vaza Barris (Fazenda Comandante). As estruturas primarias ilustradas a direita ocorrem na sequencia vertical indicada, nas rochas da Formção Lagarto-Palmares. Adaptado de D'el-Rey Silva (1992). Detalhes no texto.

intercalated within beds of Lagarto sandstones, in the largest site of economic exploitation of the latter rocks, in the same locality of Figure 8a; and 2 - layers of Palmares sandstones and polimictic conglomerates with crystalline basement-derived, $\leq 5 \mathrm{~cm}$-size, rounded clasts, intercalated with layers of Lagarto sandstones displaying typical symmetric wave ripples $\approx 5 \mathrm{~cm}$ across, about $50 \mathrm{~km}$ into the craton, to the south of the Itabaiana dome area.

The Jacare Formation (D'el-Rey Silva 1992) consists essentially of micaceous, light brown, homogeneous to variegated and $10-100 \mathrm{~cm}$ thick layers of metasiltites (Fig. 8c) with subordinated, $1-10 \mathrm{~m}$ thick lenses of fine- to medium-grained, light brown metasandstones. The metasiltites are mappable in gradual transition from the Lagarto-Palmares Formation along an E-W trending band in the southern part of the area and in the core of the Paripiranga anticline. The best exposures are along section LL' (Fig. 9), where thickness is $\approx 150-200 \mathrm{~m}$, and in the core of the Paripiranga anticline where it is much thinner (section BB', Fig. 5). In the vicinity of faults and shear zones, these rocks attain a dark brown-black colour, are silicified and indurated, displaying a vitreous texture (e.g.: outcrops along section LL' and along the Jacaré fault).

The Frei Paulo Formation is $\approx 100 \mathrm{~m}$-thick to the west of the Simão Dias dome (sections $\mathrm{BB}^{\prime}$ and $\mathrm{CC}^{\prime}$ ), and $\approx 300 \mathrm{~m}$ to $\leq 500 \mathrm{~m}$ elsewhere, particularly in the Vaza Barris valley area (sections DD', EE', FF'). It comprises several lithotypes: light grey to brown, silty and variegated phyllites (Fig.8d) with local intercalations of carbonate-cemented arkosic metasandstones and wackes, quartz-sericite-chlorite phyllites and metagreywackes (Fig.8e), metarhythmites consisting of thinly interbedded black phyllites, metasiltites, calcilutites and silty phyllites (Fig.8f), and local, thinly interbedded metalimestones and metagreywackes (Fig.8g). Basic-inter- mediate metavolcanics may be present, as the $\leq 10 \mathrm{~m}$ thick lenses found to the east of the Itabaiana dome (section $\mathrm{JJ}^{\prime}$ ).

Each of the lithofacies of this formation dominates but is not exclusive in one part of the area. To the south of the Escarpa fault, the Frei Paulo Formation consists of variegated silty phyllites (FP1, Fig. 3). To the north of the Mocambo fault, the Frei Paulo Formation commonly consists of light browncream silty phyllites, with mappable bodies of fine- to medium-grained, brownish-greenish grey, calcite-cemented metasandstones, petrographically similar to the Lagarto-Palmares (meta)sandstones and lithic (meta)greywackes (FP2). Between the Escarpa and Pelada faults, and eastwards of the Itabaiana dome (FP3, Fig.3), the dominant lithofacies are the green-blue grey, pyritous, quartz-sericite-chlorite phyllites, metagreywackes, metarhythmites, minor lenses of metasandstones and interbedded metagreywackes and metalimestones.

The Vaza Barris Group occurs only to the north of the Itaporanga fault (Fig.3) and is a $\approx 2000 \mathrm{~m}$-thick sequence unconformably overlying the previous formations and the crystalline basement. It comprises the Palestina metadiamictites and the Olhos D'agua metacarbonates and metarhythmites.

The Palestina Formation consists of metadiamictites, pebbly phyllites and minor phyllites, with local lenses of quartzites. These rocks contain granules, pebbles and cobbles of basement rocks, as well as quartzites, phyllites and metacarbonates. These strain markers are commonly flattened and elongated, and are all supported by a green-blue grey, generally fine-grained and foliated sericite-chlorite matrix (Fig. 10a). The contact with the Frei Paulo Formation is commonly obscure, although it appears locally to be gradational (section $\left.\mathrm{JJ}^{\prime}\right)$. The formation is also seen in close proximity to the crystalline basement and the Itabaiana Formation, which may suggest unconformable relationships. The typical area of occurrence is between the Escarpa and Pelada faults (the Vaza Barris river area), where the thickness is $>500 \mathrm{~m}$ and $>10 \mathrm{~cm}$ size clasts are common. Around the Simão Dias dome the thickness is $\leq 100 \mathrm{~m}$, the matrix is siltier than anywhere else and $>10 \mathrm{~cm}$ size clasts are rare, although Im-size blocks of granitic rocks are found near the western end of the trace of the Simão Dias fault, to the WNW of the Simão Dias dome. To the east of the Itabaiana dome, the metadiamictites occur along the Jacarecica river (Fig.7b) above variegated phyllites, quartz-sericite-chlorite phyllites and intercalated metasandstones of the Frei Paulo Formation. It contains boulders and pebbles of Itabaiana quartzite and Lagarto-Palmares metasandstones (Fig.1Ob) never found in the rest of the area or described in the literature (D'el-Rey Silva 1992).

The Olhos D'agua Formation consists of metacarbonates that conformably overlie the Palestina diamictites, but are also seen highly deformed in contact with the Lagarto-Palmares Formation, in the SW corner of the area, and also with the crystalline basement, along the Simão Dias and Itaporanga faults (Fig. 3). It comprises three different lithofacies (base to top): laminated metacarbonate rhythmites; oolitic metalimestones and metadolostones; mixed metacarbonate and siliciclastics (metarhythmites). The thickness is $\geq 1300 \mathrm{~m}$ around the Simão Dias dome and probably also to the north of the Pelada fault. It seems to be much less, perhaps $\approx 200 \mathrm{~m}$, possibly due to tectonic thinning, to the south of the Itabaiana dome. The Olhos D'água Formation also occurs in the NW corner of the area and in two bodies cut by the Propriá fault, to the east of the Itabaiana dome (Fig. 3), where the laminated metacarbonate rhythmites dominate.

The best exposures are from the Simão Dias dome to the north (A A', Fig. 5). The section starts with hundreds of metres of laminated metacarbonate rhythmites, which consist of $\leq 10 \mathrm{~cm}$-thick interbedded layers of light and dark grey-black, fine-grained metalimestones, with intercalated $\leq 1 \mathrm{~cm}$-thick layers of light brown metasiltites, brown to purple metapelites 
and chert (Fig.10c). Small- to medium-scale planar cross stratifications are found locally. These rocks pass up section into a sequence (probably also 100's of metres thick) of metalimestones and metadolostones consisting of interbedded, $\leq 10 \mathrm{~cm}$-thick layers of fine-grained, black metalimestones in many places oolitic and pelloidal, with oncoid structures (Fig.10d). This lithofacies also contains $<10 \mathrm{~mm}$-thick intercalations of brown metapelite, and 10$100 \mathrm{~m}$-thick layers of grey to light-brown metadoloarenite displaying small-scale planar cross stratification, wave-like erosion surfaces, intraclasts and graded bedding (Fig.10e).

Upwards, this sequence passes gradually into hundreds of metres of metarhythmites, which consist of fine-grained, 10$100 \mathrm{~cm}$ thick beds of black limestone, intercalated with 1$10 \mathrm{~cm}$ thick layers of brown to red-brown, commonly variegated, pyritic metapelite (Fig. 10f). These metarhythmites form the WNW-ESE trending hills that occur along the Escarpa and Pelada faults, and the siliciclastic layers become increasingly significant northwards. Close to the northwestern side of the Itabaiana dome, along the Salgado river, the metarhythmites contain $10-100 \mathrm{~cm}$ thick intercalations of dark grey-black phyllite (D'el-Rey Silva 1992).

\section{STRATIGRAPHY OF THE SOUTHERN PART OF} THE SERGIPANO BELT The definition of the Simão Dias Group as a craton-basin continues blanket of siliciclastics in the southern part of the belt (Fig. 11) led to redistribute the cratonic domain sediments, all previously incorporated in the Estancia Group by Saes (1984), and resulted in the lateral correlation with the metasediments of the miogeoclinal domain. The Estancia Group (D'el-Rey Silva 1992) comprises basal arkosic sandstones, argillites and diamictites (Juete Formation) overlain by carbonates (Acaua Formation), and correlates with the Miaba Group, the base of the miogeoclinal domain, where the Simão Dias and Vaza barris groups also occur.

Moreover, taking into account the conclusive evidence for sedimentary, metamorphic, structural and geophysical continuity between the cratonic, miogeoclinal and eugeoclinal domains of the belt, despite of their faulted boundaries (D'elRey Silva 1992, 1995a), the Estancia-Miaba, Simão Dias and Vaza Barris groups correlate with the Macurure Group metasediments to the north. The age of the sedimentation in the Sergipano basin has been constrained more recently by U-Pb data from Macurure metavolcanics and other isotopic data pointing to a $1,000 \mathrm{Ma}$ old event of rifting recorded in most of the Borborema Province (Brito Neves et al. 1993).

The Juete-Itabaiana/Ribeiropolis lateral correlation is warranted by the fact that these are siliclastic sediments unconformably overlying the crystalline basement and overlain by carbonates of the laterally equivalent Acaua and Jacoca formations. Moreover the meta-arkosic sandstones and redbrown phyllites of the Itabaiana Formation may be correlated with arkosic sandstones and red-brown argillites in the Juete Formation of Silva Filho et al. (1978 a,b) and Saes (1984), and the same is valid for conglomerates and diamictites in both environments. This correlation was in fact done by Silva Filho et al. (1978 a,b), including even the basal conglomerates and quartzites of the Macurure Group, deposited around the Jirau do Ponciano dome.

Megasequence stratigraphy in the Sergipano Belt The basic principles of sequence (and seismic) stratigraphy (Hubbard et al. 1985, Wagoner et al. 1987, ChristieBlick 1991) imply to study sedimentary successions in terms of the arrange of facies and associated discontinuities, either on surface or through seismic reflection data. These principles were established in Phanerozoic areas but have more recently been also applied to Proterozoic basins (e.g. Christie-Blick et al. 1988, 1995, Knoll et al. 1995, Saylor et al. 1995).

Due to a poor biostratigraphic resolution, definition of Neoproterozoic depositional sequences is commonly more difficult than of Phanerozoic counterparts (Christie-Blick et al. 1995). These authors established several points for physical recognition of sequence boundaries, i.e. unconformities and correlative conformities, and emphasized that successful studies are easier to achieve in less deformed, $\geq 5 \mathrm{~km}$-thick stratigraphic sections with relatively continuous exposures along strike.

The southern part of the Sergipano Belt is not the best area for such purposes, particularly because the D1-D2 deformation brought into parallelism the S0-S1-S2 planes in large tracts of the area (D'el-Rey Silva 1992, 1995b); furthermore, continues outcrops are uncommon, although there are numerous of good quality. Even so, we list below some of the evidence indicating that important unconformities may have existed within the stratigraphic succesion of the study area: 1 - some conglomeratic facies intercalated in the Itabaiana and Ribeiropolis formations may have been incised valleys; 2 uplift and erosion of internal parts of the basin as recorded by the Ribeirópolis and Palestina diamictites; $\mathbf{3}$ - the wide variety of lithofacies; 4 - the lack of some formations, like the Ribeirópolis and Jacoca, around the Itabaiana dome, may be interpreted as non-depositional surfaces; 5 - moreover, concordant strata do not rule out the existence of unconformities in a basin (Christie-Blick et al. 1995).

The tracing down of systems tracts within sedimentary sequences would be too speculative in a section across the Sergipano basin. However, the establishment of boundaries of megasequences is feasible, as an amalgamation of siliciclastic or carbonate sequences, and has allowed the recognition of two distinct sedimentary cycles in the southern part of the Sergipano Belt (Cycles I and II, Fig. 11; D'el-Rey Silva 1992). Cycle I comprises the lower siliciclastic megasequence (Juete-Itabaiana and Ribeiropolis formations) and the lower carbonate megasequence (Acaua-Jacoca Formation). Cycle II comprises the upper siliciclastic megasequence (Simão Dias Group-Palestina Formation) and the upper carbonate megasequence (Olhos D'água Formation). These cycles allow to interpret basin evolution in terms of periods of extensional tectonism followed by tectonic quiescence (discussed ahead in this paper), instead of understanding evolution of each group individually, and thus justifying group boundaries within a megasequence (Fig. 11), similarly of what has been done in other Neoproterozoic areas (e.g. Christie-Blick 1995).

\section{THE SERGIPANO BASIN Lithofacies analysis}

Within the Lower Siliciclastic Megasequence, deposition started with alluvial/fluvial sediments in a continental environment (trough cross-bedded basal conglomerates, conglomeratic sandstones, diamictites, arkoses and argillites of the Juete-Itabaiana Formation, and continued with the progradation of the bulk of $\leq$ lm-size planar cross-bedded, relatively well-sorted and pure Itabaiana quartzites, which compare with other siliciclastic sequences deposited in a well-washed, shallow marine environment (cf. Walker 1985). The lithofacies of interbeded arkosic metasandstones and red brown phyllites may be interpreted to indicate uplift and erosion of inner-basin crystalline basement areas or blocks (cf. Dickinson and Suczek 1979), whereas the Ribeirópolis phyllites record the upper and finer fraction invaded at times by intrabasinal clasts and minor volcanics.

In the Simão Dias Group, the vertical succession of primary structures of the Lagarto-Palmares Formation strongly suggests increasing energy in the sedimentary environment (cf. Nio et al. 1980, Tillman 1985) and compares with those expected in coarsening-upwards siliciclastic sequences de- 

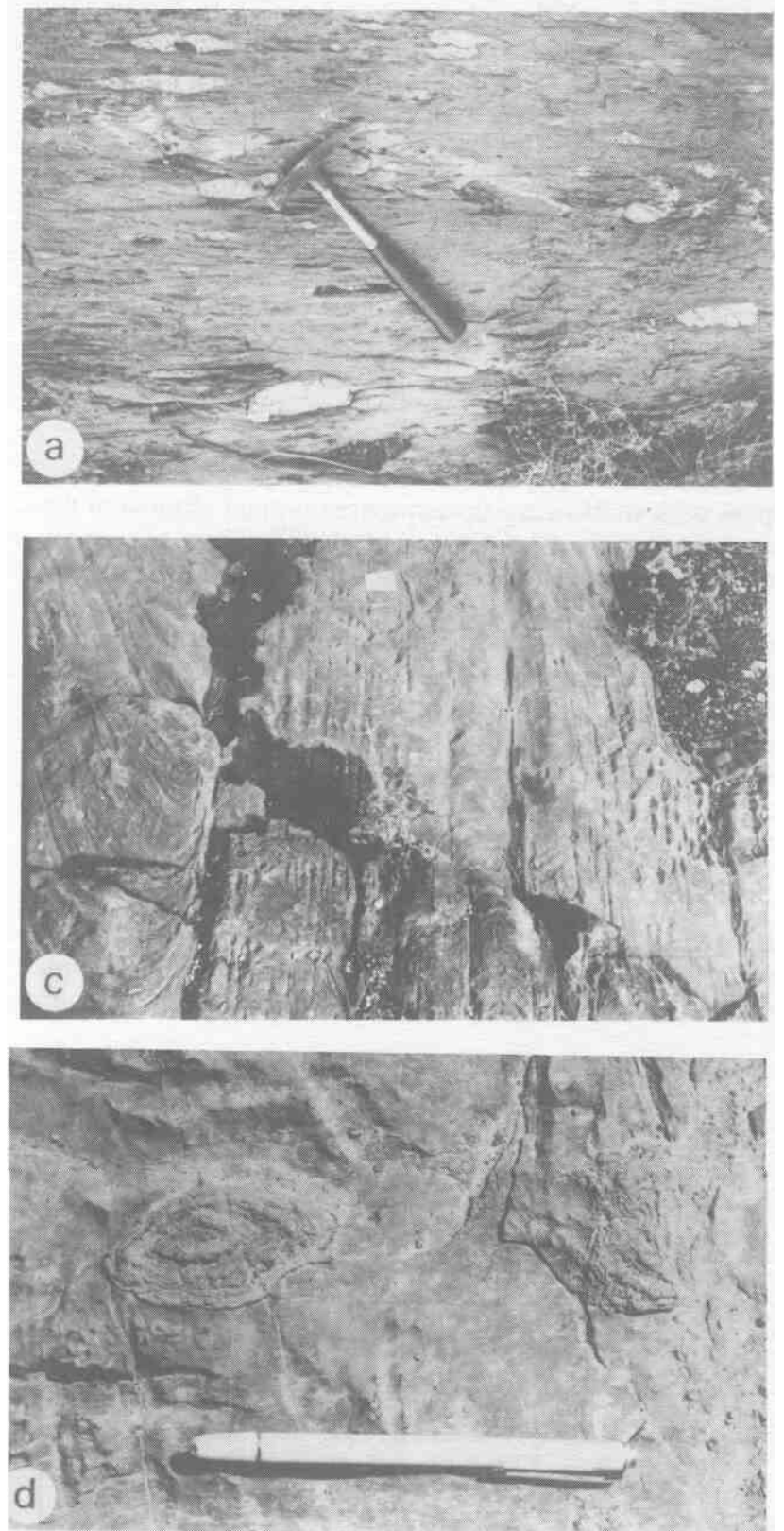

Figure 10 - The Vaza Barris Group: a - Highly foliated Palestina metadiamictite with flattened clasts of basement rocks, Vaza Barris River valley (to the west of the Itabaiana dome); $b$ - Palestina metadiamictite with boulders of Itabaiana quartzite and Lagarto-Palmares metasandstone, Jacarecica river, to the east of the Itabaiana dome; $c$-Thinly laminated metalimestone in the basal unit of the Olhos D'água Formation, S of the Simão Dias dome; $d$-Oncolitic black metalimestone of the intermediate unit; $e$-Wave-reworked dolomitic layers of the intermediate unit, NW of Simão Dias (note the intracalasts, the gradded bedding and the arrowed shrinkage fractures); $f$-Interlayered black metalimestone and variegated phyllite of the upper unit, $d$-f are from outcrops along section AA' (Fig. 5).

Figura 10 - O Grupo Vaza Barris: a -Metadiamictito Palestina muito foliado e exibindo clastos achatados de rochas do embasamento, em afloramento a oeste do domo de Itabaiana; b - Metadiamictito Palestina com matações e seixos de quartzito Itabaiana e meta-arenito Lagarto-Palmares, ao longo do rio Jacarecica a leste do domo de Itabaiana; c - Metacarbonatos fmamente acamadados da unidade basal da Formação Olhos D'água, a sul do domo de Simão Dias; d - Metacarbonato oncolltico da unidade intermediaria; e - Camadas de dolomite da unidade intermediária, mostrando evidencia de retrabalhamento por ondas durante a sedimentação- $\mathrm{f}$ Metacarbonato cinza escuro a preto intercalado com filito na unidade superior, d-f são de afloramentos ao longo da seção AA' (Fig 5). 
posited on shallow marine platforms (shelf sandstones, cf. Walker 1985). The basal unit matches the typical interbedded sandstone-and-mudstone facies deposited by storm-induced turbiditic currents below the storm wave base (cf. Walker 1985, Tillman 1985). The small-scale, wave-ripple cross stratification, with local indications of bidirectional flows, and the sand-mud couplets in the bottom of the upper unit of this formation, with muddy layers commonly disrupted (Fig. 8), indicate inteftidal to subtidal environments (cf. Visser 1980, Tillman 1985) and suggest the action of wave-reworking processes or even the overload of thick sandstone layers being deposited. The grain size, the parallel lamination, the disrupted muddy layers, and some parallel cross stratifications of the Palmares sandstones compare with the cross-bedded sandstone facies deposited above the tidal current base, where stronger currents do exist (cf. Walker 1985). Parallel-laminate, fine-grained siliciclastics such as the Jacare metasiltites and Frei Paulo variegated phyllites may be interpreted as distal sediments deposited below the storm-wave base, with eventual contribution of turbiditic tongues to form the sandy lenses. The assemblage of Frei Paulo quartz-sericite-chlorite phyllites, metagreywackes, metarhythmites and metavolcanics is very similar to those commonly found in distal, restricted, and relatively deeper-water environments associated with volcanism, e.g. in the Mesoproterozoic of Canada (cf. Wardle and Bailey 1981) and also in the Riacho do Pontal Fold Belt (Fig. 1, Gomes 1990). The lithofacies of interbedded metacarbonates and pebbly metagreywackes, already described in other Neoproterozoic areas (Miller 1983), has also been recognised in Cretaceous deep waters of North America (Sliler et al. 1991).
Diamictites Although these rocks may be formed by meltwaters, glaciogenic processes, debris and mud flows (Eyles and Mial 1984), commonly the clasts suply is mostly induced by extensional tectonic processes in all sedimentary environments (Eyles 1993). The Ribeirópolis and Palestina pebbly phyllites and diamictites most probably indicate tectônically and gravity-induced mass flows operating in the basin, in agreement with earlier suggestions by Humphrey and Allard (1969). Evidence are the thickness variation, the nature and the size of some clasts locally observed close to regional faults. Negative evidence are the lack of glaciation-related clasts, striated pavements, and extra-basinal clasts in the study area.

Carbonates The Jacoca and Olhos D'água carbonates compare with shallowing-up sequences typical of most of the Proterozoic platforms (cf. Grotzinger 1989). These sequences normally have basah offshore shelf facies (parallel-laminated and thinly intercalated carbonate and fine siliciclastics or distal turbidites), and pass into subtidal-intertidal facies, where oolites, intraclasts and wave-reworked structures recording a more agitated environment (e.g. Herrington and Fairchild 1989). Similarly, both carbonate formations in the Itabaiana dome area pass to rhythmites comparable to the limestone rhythmite facies commonly developed along ramps leading to relatively deeper environments (cf. Hoffman 1974, Markello and Read 1981).

Paleogeography and syn-depositional tectonics Several data from the literature of the Sergipano Belt (summary in D'el-Rey Silva 1992) indicate that the Sergipano

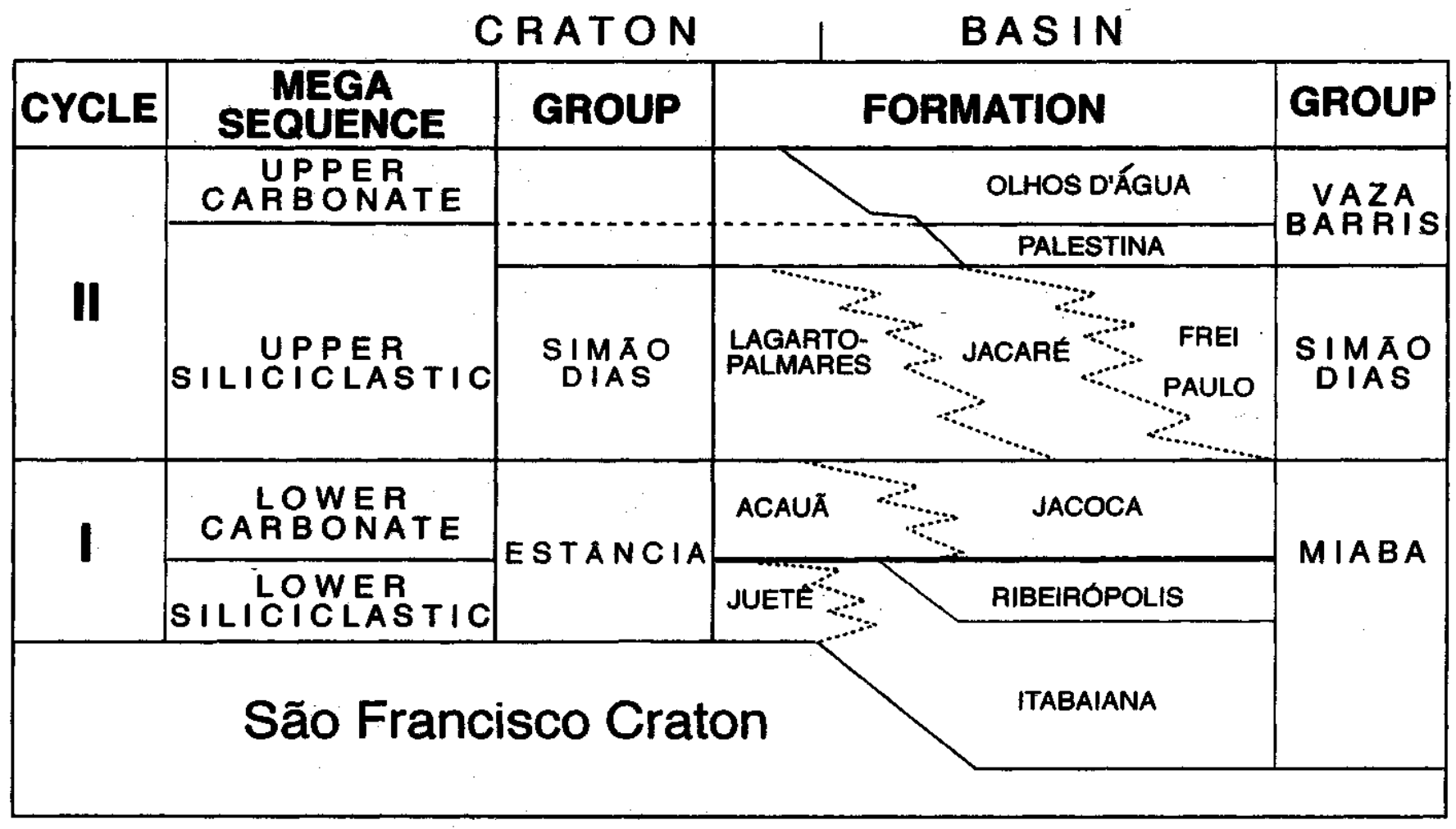

Figure 11 - Stratigraphic framework showing the craton-miogeoclinal lithological continuity and the summary megasequence stratigraphy for the southern part of the Sergipano Belt. From D'el-Rey Silva (1992). See text.

Figura 11 - Esquema estratigráfico enfatizando a continuidade litológica e sumarizando a estratigrafia de megasequencias na parte sul da Faixa Sergipana. Adaptado de D'el-Rey Silva (1992). Detalhes no texto. 
basin was asymmetric and deepened eastwards and northwards from the NNE margin of the São Francisco Craton. To the west of the Tucano basin (Fig.2), the sediments deposited in the cratonic environment are less than a few 100'm-thick and consist of local Juete conglomerates and Acaua carbonates, which directly overlap the craton basement. The sediments deposited in the basin are siliciclastic and belong to the Frei Paulo and Palestina Formations. To the east of the Tucano basin, the cratonic sediments are generally $=1-3 \mathrm{~km}$ thick (Silva Filho 1982, Saes 1984) whereas in the basin total thicknesses is $\approx 4 \mathrm{~km}$ around the Itabaiana dome (Davison and Santos 1989, D'el-Rey Silva 1992).

Wide variation of lithofacies and thicknesses associated with regional faults, as in the Sergipano basin, have been described and interpreted as well-documented examples of sedimentary infilling under a syn-depositional extensional regime (e.g. Mitchell and Owens 1990, Collier 1991). Actually, the abundant evidence for tectônically controlled sedimentation up to the deposition of the third megasequence (Fig. 10) allows to interpret most of the regional thrust faults in the southern part of the Sergipano Belt as positively inverted normal faults (Fig. 3). The data also strongly suggest that the Itabaiana and Simão dias basement domes started to evolve as paleohighs, and the area between the Escarpa and Pelada faults evolved into a fault-bounded, long-lived and relatively deeper trough during basin evolution (the Vaza B arris trough of D'el-Rey Silva 1992) which extends up to $300 \mathrm{~km}$, to the west of the Itabaiana dome, in an otherwise shallow water basin. The trough may have stretched also to the east, in the direction of the present Atlantic ocean.
In fact, all the formations are much thinner $(0-100 \mathrm{~m})$ around the Simão Dias dome, exception for the Olhos D'água carbonates, and around the Itabaiana dome, exception for the Itabaiana quartzites. On the contrary, the greatest accumulations of finer siliciclastics $(\geq 500 \mathrm{~m})$ is recorded between the Escarpa and Pelada faults, as well as to the north of the Mocambo fault (Fig. 3). One could argue for tectonic thinning of the siliciclastic sediments above the Itabaiana quartzites, instead of a stratigraphic thinning towards the domes. However, the fact that the Ribeirópolis Formation is actually missing somewhere around the Itabaiana dome, without evidence of tectonism in the contact Itabaiana-Jacoca formations, together with preservation of primary structures in the basal contacts of the Itabaiana and Ribeiropolis formations, around both the domes, does not recommend the tectonic interpretation, although it may have had some participation, enhancing the thickness contrast.

The Miaba Group The (Juetê-)Itabaiana Formation changes from the muddy and conglomeratic basal lithofacies, up to the $\leq 30 \mathrm{~m}$ thick on the craton and regionally, even around the two domes, to well-washed quartzites up to $200 \mathrm{~m}$-thick, in the southern part of the Itabaiana dome, reaching $\approx 750 \mathrm{~m}$ to the west and east of it. This change happens across the trace of the Simão Dias and Itaporanga faults, and strongly suggests that the site of the future Itabaiana dome evolved into a deeper depocenter which captured most of the sediment supply. Ribeiropolis volcanics occur in the western side of the Simão Dias dome, whereas conglomeratic lithofacies occur locally

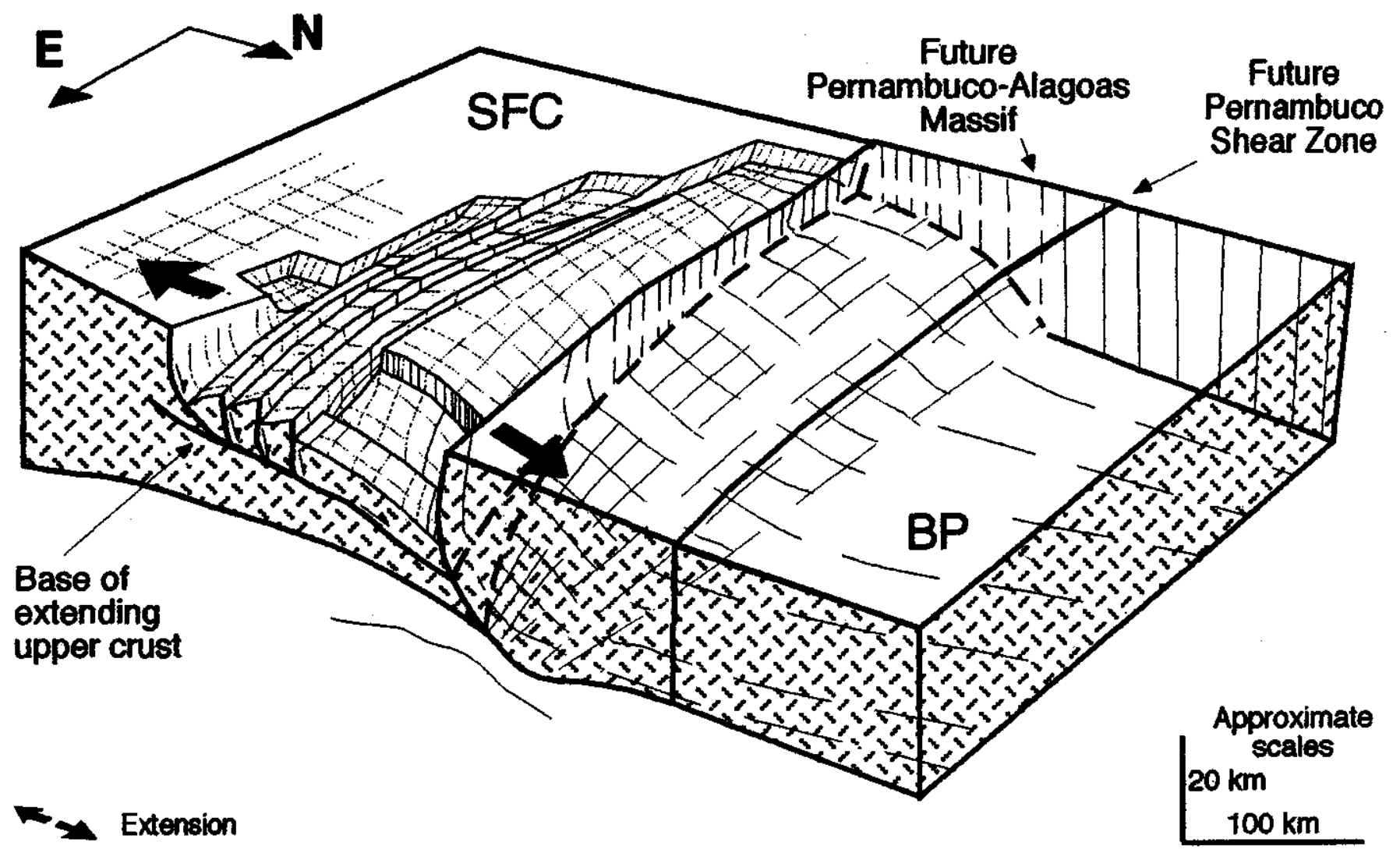

Figure 12 - Cartoon to illustrate the preferred mode of the continental extension that led to the Neoproterozoic Sergipano basin and to the northern margin of the São Francisco Craton. From D'el-Rey Silva (1992). See text.

Figura 12 - Modelo esquemático da extensão continental que resultou na bacia Sergipana, no Neoproterozóico, ao longo da margem norte do Cráton do São Francisco. 
in the eastern and western sides of the Itabaiana dome (Ribeirópolis diamictites displaying $\approx 1.2 \mathrm{~m}$ size clasts of basement rocks were found close to the Mocambo fault and to the Itabaiana dome by Humphrey and Allard 1969). The thicker Jacoca carbonates die to the west and northwest of the Itabaiana dome and become increasingly siliciclastic towards the Vaza Barris trough, and to the north of the Mocambo fault.

The Simão Dias Group By that time the basin received thicker and relatively deep water sediments of the Frei Paulo Formation to the west and to the east of the Itabaiana dome, whereas sandstone lenses are recorded within the phyllites, particularly to the north of the trough (Fig. 3).

The Vaza Barris Group The Vaza Barris trough records the thickest section of the Palestina diamictites, and also records the gradual passage from Olhos D'água carbonates into carbonate metarhythmites, across the trace of the Escarpa fault (section AA', Fig. 5).

Continental margin extensional model We prefer a simple shear style of crustal extension (cf. Wernicke and Burchfiel 1982) for the opening of the Sergipano basin above a linked listric detachment (cf. Gibbs 1984). Extension of the northern margin of the Sao Francisco Craton was probably oblique (Fig. 12; cf. Gibbs 1987). The basin probably evolved from an initially intracratonic setting into an oceanic basin. Such interpretation is supported by the island-arc geochemical signature of the basic-ultrabasic magmatism of the Caninde domain and by deposition of the Palestina diamictites in a $\geq 300 \mathrm{~km}$ long trench that indicate an important event of crustal extension (the Vaza Barris trough of D'el-Rey Silva 1992, 1995b). In such a model, upper crust extension would take place above a ramp-flat listric basal detachment, and the cumulative strain of the extending hangingwall was accommodated by a system of synthetic and antithetic, planar and listric normal faults.

The listric fault model is favoured because: $\mathbf{a}$ - the basin must have been asymmetric; $\mathbf{b}$ - thicknesses generally increase to the north, away from the São Francisco Craton; $\mathbf{c}$ - the Palestina diamictites are deposited in a long lived trough; $\mathbf{d}$ extensional fault activity is indicated by the presence of large polylithic clasts of both basement and cover sediments in the succession adjacent to the Simão Dias and Mocambo faults, pointing out to uplift-erosion of footwall and possibly hangingwall blocks twice during the evolution of the basin; and $\mathbf{e}$ - the lack of multiple wedge shaped sedimentary sequences within the succession. These would be produced if extension in the basin margin dominantly occurred by an array of domino style faults (e.g. Davison 1989), or even in a flexuralcantilever model (cf. Kusznir et al. 1991).

TECTONIC IMPLICATIONS FOR THE BELT AND THE SAO FRANCISCO CRATON The stratigraphic analysis here presented rules out thrust belt-foreland basin models to explain the origin of the Palmares sandstones and lithic wackes, an interpretation initially adopted in the previous literature of the Sergipano Belt, as in the Introduction of this paper. In addition to the large amount of new data pointing out to another origin for the Lagarto-Palmares Formation, the sedimentary characteristics of the Palmares sandstones and wackes do not compare either with continental sedimentation described elsewhere ahead of thrust sheets (e.g. Gustavson 1974, Nichols 1987) or ahead fault-uplifted terranes (e.g. Wescott and Ethridge 1990). Similarly, the stratigraphic succession formed by the Simão Dias and Vaza Barris groups does not compare with the marine sedimentation de- veloped in foreland basins due to accretion of terranes into a passive margin, as interpreted for example in the evolution of the Appalachians and Cordilleran basins of North America (Tankard 1986).

Because the Sergipano Belt has unique and key evidence around the basement domes, and because its cratonic-miogeocline-eugeocline lithostructural continuity is a common feature in many other Neoproterozoic fold belts, in particular around the Sao Francisco Craton (e.g. Egydio da Silva et al. 1989, Gomes 1990, Uhlein et al. 1990, Pedrosa-Soares et al 1992, Farias 1995), caution is required in applying thrust belt-foreland basin models to explain the upper section of the cratonic cover related to the Riacho do Pontal, Rio Preto, Brasilia and Araçuaí Belts (Fig. 1). Instead, the voluminous sands of the upper section of the Estância domain in the Sergipano Belt (the Palmares massive sandstones) must have come from southern sources in the São Francisco Craton, once the detailed sedimentary analysis done by Saes (1984) within his Lagarto and Palmares formations does not support a northern source.

CONCLUSIONS Tectônically controlled sedimentation resulted in the deposition of a $1-4 \mathrm{~km}$ thick miogeoclinal wedge of carbonates and siliciclastics in the southern part of an asymmetric basin that afterwards evolved into an ocenic basin, the closure of which formed the Sergipano Belt in the northern margin of the São Francisco Craton. The stratigraphic record of the southern part of the belt is divided in the Estancia-Miaba, Simão Dias and Vaza Barris groups. These groups correlate laterally with the Macurure Group of the northern part of the belt and comprise ten formations interpreted as part of two sedimentary cycles and four megasequences which accounts for the spatial distribution of lithofacies, thickness and sedimentary processes throughout the basin.

A new tectonic-sedimentary entity in the Sergipano Belt (the Simão Dias Group and the Upper Siliciclastic Megasequence as a whole), most likely resulted from a uplift and erosion of the São Francisco Craton and also from basement blocks uplifted to the $\mathrm{N}$ of the Itabaiana dome area, implying that massive sandstones overlying the cratonic sedimentary cover (the Palmares sandstones) are not the product of the erosion of a deforming Sergipano Belt. The similarities of the sedimentary record, the craton-belt lithostructural continuity and the megasequence stratigraphy of the Sergipano Belt compare well with other Neoproterozoic cratonic margins, pointing out to a probable common tectonic evolution for the Neoproterozoic cratons, basins and belts. This issue is to be adressed in more detail in a future publication where basin evolution is further discussed, together with the origin of the Simão Dias Group and its implication for the evolution of the São Francisco Craton and peripheral Neoproterozoic basins.

Acknowledgments L.J.H. D'el-Rey Silva thanks CNPq, Brazil, for Grants 200025/88-3, 301102/92-9, 400037/93-9 and 520241/95-9, and the support he had from his family, essential for completion of his $\mathrm{PhD}$ thesis. $\mathrm{Mr}$. Pedro Dias dos Santos and his family, runners of the Irmaos Vasconcelos Hotel, in the town of Lagarto, Sergipe State, are thanked for their hospitality along the period of field work (1987-1995). Reading and criticism by M.A.Dardenne and R.A.Fuck (UnB-IG, Brazil), by K. Ericksson and by two anonimous referees, has resulted in general improving of on an earlier manuscript. J.R.F. Torquato (UFCe) and E.F. Jardim de Sá (UFRN) are thanked for their final review and criticism on this paper. 


\section{REFERENCES}

ALLARD, G.0.1969. The Propria' geosyncline, a key tectonic element in the continental drift puzzle of the South Atlantic. XXIII Congresso Bmsileiro Geologia, Salvador, Anais SBC 1:47-59

ALLARD, G.O. \& HURST, V.J. 1969. Brazil-Gabon geologic link supports continental drift. Science 163:528-532

ALMEIDA, F.F.M. de, HASUI, Y., BRITO NEVES, B.B. de \& FUCK, R.A. 1981. Brazilian Structural Provinces: an introduction. Earth Sciences Review, Special Issues 17: 1-29

AMORIM, J.L., TORRES, H.H.F \& SILVA FILHO, M.A da 1993. O Complexo de embasamento da Faixa Sergipana na regiao de Jirau do Ponciano (Al): Estratigrafia, evolu?ao tectonometamdrfica e potencialidade metalogene'tica. XV Simposio de Geologia doNordeste, Natal, Boletim de Resumos SBG-NE, 240-242

AMORIM, J.L. \& TORRES, H.H.F. 1994.0 limite entre as Faixas Sergipana e Sul-Alagoana. XXXVIII Congresso Brasileiro de Geologia, Balnedrio Camboriu, Boletim de Resumos Expandidos SBG 1:250-252

BRITO NEVES, B.B. de \& CORDANI, U.G. 1973. Problemas geocrono!6gicos do "Geosinclinal Sergipano" e do seu embasamento. XXXVI Congresso Brasileiro de Geologia, Aracaju, Anais SBG 1:67-76

BRITO NEVES, B.B. de, SIAL, A.N. \& BEURLEN, H. 1977.0 sistema de dobramentos Sergipano. / Simposio do Crdton Sdo Francisco e sua faixas marginals, Salvador, Atas Reuniao Preparatoria, SBG-SME-CPM, 369-391

BRITO NEVES, B.B. de, SIAL, A.N., RAND, H.M. \& MANSO, V.V. 1982. The Pernambuco-Alagoas Massif, Northeast Brazil. Revista Brasileira de Geociencias 12(1-3):240-250

BRITO NEVES, B.B. de, VAN SCHMUS, W.R., BABINSKI, M. \& SABIN, T. 1993.0 evento de magmatismo de 1,0 Ga nas faixas moveis ao norte do Crdton Sao Francisco. II Simpósio sobre o Cráton São Francisco, Salvador, Anais SBG-SGM, 243-245

CAMPOS NETO, M. da C. \& BRITO NEVES, B.B. de 1987. Consideracoes sobre a organização e geometria do Sistema de Dobramentos Sergipano. I Simpósio Nacioanl de Estudos Tectônicos, Salvador, Boletim de Resumos, UFBa, 90-93

CHAVES, J.M. 1991. Macicos Coronel Joao Sa e GhSria. Petrologia de granitoides no domfnio Macurure, Faixa Sergipana (NE Brasil). Unpublished MSc thesis, UFBa, Salvador, 153p.

CHRISTIE-BLICK, N. 1991. Onlap, offlap, and the origin of unconformity-bounded depositional sequences. Marine Geology 97:35-56

CHRISTIE-BLICK, N., GROTZINGER, J.P. \& VON DER BORCH, C.C. 1988. Sequence stratigraphy in Proterozoic successions. Geology 16:100-104

CHRISTIE-BLICK, N., DYSON, I.A. \& VON DER BORCH, C.C. 1995. Sequence stratigraphy and the interpretation of Neoproterozoic earth history. Precambrian Research 73:3-26

COLLIER, R.E. 1991. The Lower carboniferous Stainmore Basin, N. England: extensional basin tectonics and sedimentation. Journal Geological Society London 148, Part 2, 379-390

DAVISON, I. 1989. Extensional domino faults tectonics: Kinematics and geometrical constraints. Annales Tectônicae III:12-24

DAVISON, I. \& SANTOS, R.A. dos 1989. Tectonic Evolution of the Sergipano Fold Belt, NE Brazil, during the Brasiliano Orogeny. Precambrian Research 45:319-342

D'EL-REY SILVA, L.J.H. 1992. Tectonic evolution of the southern part of the Sergipano Fold Belt, northeastern Brazil. Unpublished PhD Thesis, Royal Holloway University of London, 257p.

D'EL-REY SILVA, L.J.H. 1993. Evolucao tectônica da Faixa Sergipana e implica96es para o sistema Brasiliano-Panafricano. II Simpósio sobre o Cráton São Francisco, Salvador, Anais SBG/SGM, 246-248

D'EL-REY SILVA, L.J.H. 1994. The Sergipano Fold Belt and Implications for Proterozoic Tectonics. XXXVIII Congresso Brasileiro Geologia, Balne ario Camboriu, Boletim Resumos Expandidos SBG 1:265-267

D'EL-REY SILVA, L.J.H. 1995a. The evolution of basement gneiss domes of the Sergipano fold belt (NE Brazil) and its importance for the analysis of Proterozoic basins. Journal of South American Earth Sciences 8(3/4):325-340

D'EL-REY SILVA, L.J.H. 1995b. Tectonic evolution of the Sergipano Belt, NE Brazil. Revista Brasileira de Geociencias 25, in press

DICKINSON, W.R. \& SUCZEK, C.A. 1979. Plate Tectonics and sandstone composition. Bulletim American Association Petroleum Geologists 63:2164-2182

EGYDIO da SILVA, M., KARMANN, I. \& TROMPETTE, R. 1989. Litoestratigrafia do Supergrupo Espinha90 e Grupo Bambuf no Noroeste do Estado da Bahia. Revista Brasileira de Geociencias 19:141-152

EYLES, N. 1993. Earth's glacial record and its tectonic setting. Earth Science Reviews 35:1-248.
EYLES, N. \& MIALL, A.D. 1984. Glacial facies. In: Fades Model (edited by R.G.Walker). Geosciences Canada Reprint Series 1, 2nd edition, $15-38$

FARIA, A. 1995. Estratigrafia e sistemas deposicionais do Grupo Paranod nas areas de Cristalina, Distrito Federal e Sdo Joao da Alianca-Alto Paraiso de Goids. Unpublished PhD Thesis, UnB-Brazil, 199p.

GAVA, A., NASCIMENTO, D.A. do, VIDAL, J.L.B., GHIGNONE, J.I., OLIVEIRA, E.P. de, SANTIAGO Fo, A.L. \& TEIXEIRA, W. 1983 Projeto RADAMBRASIL, Geologia. Mapa geoldgico, Folhas SC.24/25, Aracaju/Recife, escala 1:1,000,000, Rio de Janeiro, Levantamento de Recursos Naturais 30

GIBBS, A.D. 1984. Structural evolution of extensional basin margins. Journal Geological Society London 141:609-620

GIBBS, A.D. 1987. Development of extension and mixed-mode sedimentary basins. In: Continental Extensional Tectonics (edited by M.P. Coward J.F. Dewey and P.L. Hancock). Geological Society London Special Publication 28:19-33

GOMES, F.E.M. 1990. RelafSes litoestratigraTico-estruturais e evolucao tectdnica na faixa Riacho do Pontal - Regiao de Paulistana (Pi). XXXVI Congresso Brasileiro Geologia, Natal, Anais SBG 6:2843-2857

GROTZINGER, J.P. 1989. Facies and evolution of Precambrian carbonate depositional systems: emergence of modern platform archetype. In: Controls on Carbonate Platform and Basin Development (edited by P.D.Crevello, J.L. Wilson, J.F. Sarg and J.F.Read). Society Economic Paleontologists and Mineralogists Special Publication 44:79-106

GUIMARAES, J.G., SILVA R.W.S. \& TOLEDO, L.A.A. de 1991. Relat6rio Final do Projeto Sulfetos Faixa Sergipana. CBPM, Salvador-Brazil, $37 \mathrm{p}$.

GUSTAVSON, T.C. 1974. Sedimentation on gravel outwash fans, Malaspina Glacier foreland, Alaska. Journal of Sedientary Petrology 44:374-389

HERRINGTON, P.M. \& FAIRCHILD, I.J. 1989. Carbonate shelf and slope facies evolution prior to Vendian glaciation, Central east Greenland. In: The Caledonide Geology of Scandinavia (edited by R.A. Gayer) Grahan and Trotmam Publishers, 263-273

HOFFMAN, P. 1974. Shallow and deep water stromatolites in Lower Proterozoic platform-to-basin facies change, Great Slave Lake, Canada. Bulletim American Association Petroleum Geologists 58:856-867

HUBBARD, R.J., PAPE, J. \& ROBERTS, D.G. 1985. Depositional sequence mapping as a technique to establish tectonic and stratigraphic framework and evaluate hydrocarbon potential on a passive continental margin. In: Seismic stratigraphy, II. (edited by O.R. Berg and D.G. Woolverton). American Association of Petroleum Geologists, Memoir 39:79-92

HUMPHREY, F.L. \& ALLARD, G.O. 1968. The Proprid geosyncline, a newly recognised tectonic element in the Brazilian shield. International Geological Congress 23, Prague 4:123-139.

HUMPHREY, F.L. \& ALLARD, G.O. 1969. Geologia do domo de Itabaiana (Sergipe) e sua relacao com a geologia do geosinclinal de Propria, um elemento tectonico rec6m reconhecido no escudo brasileiro. Petrobrds, CENPES, Rio de Janeiro, 104p.

JARDIM de SA, E.F. 1994. A Faixa Serido (Provincia Borborema, NE do Brasil) $e$ o seu significado geodinâmico na cadeia Brasiliana/Pan-Africana. Unpublished PhD Thesis No. 3, UnB-Brazil, 803p.

JARDIM de SA, E.F., LEGRAND, J.M. \& HACKSPACHER, P.C. 1981. Contraste de estilos estruturais e metam6rficos na faixa dobrada Sergipana. Revista Brasileira Geociencias 11:128-137

JARDIM de SA, E.F., MORAES, J.A.C. de \& D'EL-REY SILCA, L.J.H. 1986. Tectônica tangencial na Faixa Sergipana. XXXIV Congresso Brasiliero Geologia, Goiania, Anais SBG 3:1246-1259

JORDAN, H. 1971. The Late Precambrian Synclinorium of Curaçá (Brazil). Geologisches Jb. 88:617-628

KNOLL, A.H., GROTZINGER, J.P., KAUFMAN, A.J. \& KOLOV, P., 1995. Integrated approaches to terminal Proterozoic stratigraphy: an example from the Olenek Uplift, northeastern Siberia. Precambrian Research 73:251-270

KUSZNIR, N.J., MARSDEN, G. \& EGAN, S.S. 1991. A flexural-cantilever simple-shear / pure-shear model of continental lithosphere extension: applications to the Jeanne d'Arc Basin, Grand Banks and Viking Graben, North Sea. In: The Geometry of Normal Faults (edited by A.M. Roberts, G. Yielding and B.Freeman). Geological Society London Special Publication 56:41-60

MARKELLO, J.R. \& READ, J.F. 1981. Carbonate ramp-to-deeper shale shelf transitions of an uper Cambrian intrashelf basin, Nolinchucky Formation, southwest Virginia Appalachians. Sedimentology 28, 573-597 
MASCARENHAS, J. de F., MISI, A., MOTTA, A.C. \& SA, J.H. da S. 1984 Provmcia Sao Francisco. In: O pre-Cambriano do Brasil (edited by Almeida, F.F.M. de \& Hasui, Y.). Editora Edgard Blucher Ltda., 46-122

MILLER, J.G.M. 1983. Upper Precambrian unconformity within the Kingston Peak Formation, Panamint Range, eastern California. Geological Society of America Abstracts with Program 15:424

MITCHELL, W.I \& OWENS, B. 1990. The geology of the western part of the Fintona Block, Northern Ireland: evolution of Carboniferous basins. Geological Magazine 127:407-426

MURPHY, J.B. \& NANCE, R.D. 1991. Supercontinent model for the contrasting character of Late Proterozoic orogenic belts. Geology 19 , $469-472$

NICHOLS, G.J. 1987. Syntectonic alluvial fan sedimentation, southern Pyrenees. Geological Magazine 124:121-133

NIO, S-D, VAN DER BERG, J.H., GOESTEN, M. \& SMULDERS, F. 1980 Dynamics and sequential analysis of a mesotidal shoal and intershoal channel complex in the eastern Scheldt (southwestern Netherlands). Sedimentary Geology 26:263-279

PEDROSA-SOARES, A.C., NOCE, A.C., VIDAL, PH., MONTEIRO, R.L.B.P. \& LEONARDOS, O.H. 1992. Toward a new tectonic model for the Late Proterozoic Aracuaf (SE Brazil) - West Congolian (SE Africa) Belt. Journal of South America Earth Sciences 6(1/2):33-47

SAES, G.S. 1984. Estratigrafia e sedimentologia do Grupo Estdncia na regido Nordeste do Estado da Bahia. Unpublished MSc Thesis, UFBa-Brazil, 107p.

SANTOS E.J., dos BRITO NEVES, B.B. de 1984. Provfncia Borborema. In: O pre-Cambriano do Brasil (edited by Almeida, F.F.M. de \& Hasui, Y.). Editora Edgard Blucher Ltda., 123-186

SANTOS, R.A., MENEZES FILHO, N.R. \& SOUZA, J.D. de 1988. Programa Levantamentos Geol6gicos Basicos; carta geologica, carta metalogenetica e provisional, 1:100.000, Projeto Carira. DNPM/CPRM, $4 \mathrm{v}$.

SAYLOR, B.Z., GROTZINGER, J.P. \& GERMS, G.J.B. 1995. Sequence stratigraphy and sedimentology of the Neoproterozoic Kuibis and Schwarzrand Subgroups (Nama Gorup), southwestern Namibia. Precambrian Research 73:153-171

SLITER, W.V., MURCHEY, B.L., MCLAUGHLIN, R.J. \& KISTLER, R.W. 1991. Permanente Terrane: history of early Cretaceous seamount formation in the eastern Pacific. Geological Society of America, 87Th Annual Cordilleran Section, Abstracts with Program, abstract 1217

SILVA FILHO, M.A. 1976. A suite ofiolitica da Geosinclinal de Proprid XXIX Congresso Brasileiro de Geologia, Ouro Preto, Anais SBG $1: 51-58$

SILVA FILHO, M.A. 1982. A evolução da porção marginal do cinturão Sergipano e sua metalogenia. XXXII Congresso Brasileiro de Geologia, Salvador, Anais SBG 2:316-324

SILVA FILHO, M.A., BONFIM, L.F.C. \& SANTOS, R.A. dos 1978a. A geossinclinal Sergipana: estrutura e evolucão. $X X X$ Congresso Brasileiro de Geologia, Recife, Anais SBG 6:2464-2477

SILVA FILHO, M.A. \& BRITO NEVES, B.B. de 1979. O sistema de dobramentos Sergipano no nordeste da Bahia. Revista SME/SGM, Série Geologia e Recursos Minerals da Bahia, Textos Basicos, 203-214
SILVA FILHO, M.A., SANTANA, A.C. \& BONFIM, L.F.C. 1978b. EvolucSo tectono-sedimentar do Grupo EstSncia: suas correlagoes. XXX Congresso Brasileiro de Geologia, Recife, Anais SBG 2:685-699

TANKARD, A.J. 1986. On the depositional response to thrusting and lithospheric flexure. International Association Sedimentologists Special Publication 8:369-394

TEIXEIRA, W. \& FIGUEREDO, M.C.H. 1991. An outline of Early Proterozoic crustal evolution in the SSo Fancisco craton, Brazil: a review. Precambrian Research 53:1-22

TILLMAN, R.W. 1985. A sectrum of shelf sands and sandstones. In R.W. Tillman, D.J.P. Swift and R.G. Walker (eds), Shelf sands and sandstone reservoirs. Society Economic Paleontologists and Mineralogists Short Courses 13:1-46

TROMPETTE, R. 1994. Geology of Western Gondwana. A.A.Balkema, Rotterdam, 350p.

UHLEIN, A., EGYDIO da SILVA, M. \& TROMPETTE, R. 1990. A faixa de dobramentos Aracuai, no Estado de Minas Gerais: uma cadeia monociclica de idade Brasiliana. XXXVI Congresso Brasileiro de Geologia, Natal, Anais SBG 6:2576-2588.

VAN SCHMUS, W.R., BRITO NEVES, B.B. de; HACKSPACHER, P. \& BABINSKI, M. 1993. Identification of crustal blocks in Northeast Brazil using Sm-Nd and U-Pb Geochronology. II Simpósio sobre o Craton Sao Francisco, Salvador, Anais SBG/SGM, 239-242

VAN SCHMUS, W.R., BRITO NEVES, B.B. de, HACKSPACHER, P. \& BABINSKI, M. 1995. U/Pb and Sm/Nd geochronologic studies of the eastern Borborema Province, Northeastern Brazil: initial conclusions. Journal South American Earth Sciences 8:267-288

VISSER, M.J. 1980. Neap-spring cycles reflected in Holocene subtidal large-scale bedform deposits: a preliminar note. Geology 10:135-140

WALKER, R.G. 1985. Ancient examples of tidal sand bodies formed in open, shallow seas. In R.W. Tillman, D.J.P. Swift and R.G. Walker (eds), Shelf sands and sandstone reservoirs. Society Economic Paleontologists and Mineralogists Short Courses 13:303-342

WARDLE, R.J. \& BAILEY, D.G. 1981. Early Proterozoic sequences in Labrador. In: Proterozoic Basins of Canada (edited by F.H.A. Campbell). Geological Survey Canada, Paper 81-10, p.331-359

WAGONER, J.C., MITCHUM JR., R.M., POSAMENTIER, H.W. \& VAIL, P.R. 1987. Seismic stratigraphy interpretation using sequence stratigraphy, part 2: key definition of sequence stratigraphy. In: Atlas of Seismic Stratigraphy (edited by A.W. Bally). American Association Petroleum Geologists, Studies in Geology, Memoir 27: 11-14

WERNICKE, B. \& BURCHFIEL, B.C. 1982. Modes of extensional tectonics. Journal of Structural Geology 4,105-115

WESCOTT, W.A. \& ETHRIDGE, F.G. 1990. Fan Deltas - Alluvial Fans in coastal settings. In: Alluvial Fans: a field approach (edited by A.H.Rachocki and M. Church). John Wiley and Sons Ltd., 195-212

MANUSCRITO A856

Recebido em 30 de setembro de 1996

Revisao dos Autores em 23 de dezembro de 1996 Revisao aceita em 23 de dezembro de 1996 